\title{
DIGITALCOMMONS
}

@WAYNESTATE-

Wayne State University

Law Faculty Research Publications

Law School

$1-1-2004$

\section{Federalism and the Federal Prosecution of State and Local Corruption}

Peter J. Henning

Wayne State University

\section{Recommended Citation}

Henning, Peter J.. Federalism and the Federal Prosecution of State and Local Corruption. 92 Ky. L.J. 75, 148 (2003)

Available at: https://digitalcommons.wayne.edu/lawfrp/263

This Article is brought to you for free and open access by the Law School at DigitalCommons@WayneState. It has been accepted for inclusion in Law Faculty Research Publications by an authorized administrator of DigitalCommons@WayneState. 


\title{
Federalism and the Federal Prosecution of State and Local Corruption
}

\author{
By Peter J. HenNing*
}

\section{INTRODUCTION}

Since the 1970s, federal prosecutors have been particularly active in

prosecuting state and local officials for corruption, even when the misconduct does not directly affect the federal government. In the past few years, federal prosecutors have secured convictions of a number of government officials or former officials, including a former governor, ${ }^{1}$ former state court judges, ${ }^{2}$ state legislators, ${ }^{3}$ mayors, ${ }^{4}$ city council members, ${ }^{5}$ a former Commonwealth attorney, ${ }^{6}$ and a variety of officers at all

" Professor of Law, Wayne State University Law School. Copyright (C 2003 Peter J. Henning. I appreciate the comments and suggestions of Ellen Podgor, Tony Dillof, Bob Sedler, and Dave Moran, and research support from Wayne State University Law School.

${ }^{1}$ United States v. Edwards, 303 F.3d 606 (5th Cir. 2002), cert. denied, 537 U.S. 1192 (2003) (Louisiana).

${ }^{2}$ United States v. Frega, 179 F.3d 793 (9th Cir. 1999) (California); United States v. Stillo, 57 F.3d 553 (7th Cir. 1995) (Illinois).

${ }^{3}$ United States v. Serafini, 233 F.3d 758 (3d Cir. 2000) (Pennsylvania); United States v. Derrick, 163 F.3d 799 (4th Cir. 1998) (South Carolina).

${ }^{4}$ United States v. Milan, 304 F.3d 273 (3d Cir. 2002), cert. denied, 123 S. Ct. 1956 (2003) (Camden, New Jersey); United States v. Fernandez, 282 F.3d 500 (7th Cir.), cert. denied, 537 U.S. 1028 (2002) (Lyons, Illinois); United States v. Orlando-Figueroa, 229 F.3d 33 (1st Cir. 2000) (Toa Alta, Puerto Rico); United States v. Tucker, 133 F.3d 1208 (9th Cir. 1998) (Compton, California).

${ }^{5}$ United States v. Williams, 264 F.3d 561 (5th Cir. 2001) (Jackson, Mississippi); United States v. Giles, 246 F.3d 966 (7th Cir. 2001) (Chicago, Illinois); United States v. Reyes, 239 F.3d 722 (5th Cir.), cert. denied, 534 U.S. 868 (2001) (Houston, Texas); United States v. Hairston, 46 F.3d 361 (4th Cir. 1995)(WinstonSalem, North Carolina).

${ }^{6}$ United States v. Carmichael, 232 F.3d 510 (6th Cir. 2000), cert. denied, 532 U.S. 974 (2001) (Kentucky). 
levels of government. ${ }^{7}$ Do federal prosecutors invade an area traditionally reserved to the states by applying federal statutes to local corruption that does not implicate the exercise of any direct federal power or the misuse of federal funds?

The question of the federal government's role in enforcing criminal laws against state and local officials has become especially relevant since the Supreme Court's decisions in United States v. Lopez ${ }^{8}$ and United States v. Morrison, ${ }^{9}$ which invalidated federal statutes because they exceeded congressional authority to regulate in areas already subject to the police power of the states. The Court relied in part on the principle of federalism embedded in the constitutional structure to limit Congress' power to regulate certain types of conduct, specifically crimes of violence.

Federalism is a structural protection inherent in the design of the Constitution and reflected in the protection afforded by the Tenth Amendment. ${ }^{10}$ Federalism limits the authority of the federal government by permitting the exercise of only the powers enumerated in the Constitution, while reserving to the states separate sovereign authority. Federalism thereby protects the rights of individuals through the division of governmental power at different levels." The Court has stated, "Just as the separation and independence of the coordinate branches of the Federal Government serve to prevent the accumulation of excessive power in any one branch, a healthy balance of power between the States and the Federal Government will reduce the risk of tyranny and abuse from either front."12 And, as the Court noted in Lopez, "Though on the surface the idea may

${ }^{7}$ United States v. VanMeter, 278 F.3d 1156 (10th Cir. 2002)(Deputy Commissioner of the Oklahoma State Department of Health); United States v. Fernandes, 272 F.3d 938 (7th Cir. 2001) (former deputy prosecutor); United States v. DeLaurentis, 230 F.3d 659 (3d Cir. 2000) (supervisor of detectives); United States v. Brown, 151 F.3d 476 (6th Cir. 1998) (employees of Detroit Housing Department); United States v. Brumley, 116 F.3d 728 (5th Cir. 1997)(Regional Associate Director of the Texas Workers' Compensation Commission).

${ }^{8}$ United States v. Lopez, 514 U.S. 549 (1995).

${ }^{9}$ United States v. Morrison, 529 U.S. 598 (2000).

${ }^{10}$ U.S. CONST. amend. X ("The powers not delegated to the United States by the Constitution, nor prohibited by it to the States, are reserved to the States respectively, or to the people.").

"See Keith Werhan, Checking Congress and Balancing Federalism: A Lesson From Separation-of-Powers Jurisprudence, 57 WASH. \& LEE L. REV. 1213, 1218 (2000) ("Federalism divides power vertically between the national government and the states.").

${ }^{12}$ Gregory v. Ashcroft, 501 U.S. 452, 458 (1991). 
seem counterintuitive, it was the insight of the Framers that freedom was enhanced by the creation of two governments, not one." 13

Although federalism is among the fundamental principles of the Constitution, it has been applied inconsistently and often with substantial controversy. ${ }^{14}$ In the past decade, federalism has undergone a revival of sorts as an additional limit on congressional authority to extend federal power; drawing on federalist arguments, the Supreme Court has struck down federal criminal laws it found beyond Congress' power to enact. In Lopez, the Court invalidated the Gun-Free School Zones Act because the conduct subject to prosecution-possession of a weapon within 500 feet of a school - was not economic activity, and therefore fell beyond congressional authority under the Commerce Clause absent some interstate movement. ${ }^{15}$ As part of its analysis, the Court noted, almost as an aside, that the states are the "primary authority for defining and enforcing the criminal law," so that "[w] hen Congress criminalizes conduct already denounced as criminal by the States, it effects a 'change in the sensitive relation between federal and state criminal jurisdiction." "16

In Morrison, the Court explicitly relied on federalism as a rationale for invalidating the civil remedy provision of the Violence Against Women Act, which permitted the plaintiff to bring a federal damages claim for

${ }^{13}$ Lopez, 514 U.S. at 576.

${ }^{14}$ See Jenna Bednar \& William N. Eskridge, Jr., Steadying the Court's "Unsteady Path": A Theory of Judicial Enforcement of Federalism, 68 S. CAL. L. REV, 1447, 1447 (1995) ("Like the Supreme Court's separation of powers jurisprudence, its federalism jurisprudence might, uncharitably, be described as 'a mess." "); Richard H. Fallon, Jr., The "Conservative" Paths of the Rehnquist Court's Federalism Decisions, 69 U. CHI. L. REV. 429, 439-40 (2002) ("There is no agreed-upon definition of constitutional federalism. As a structural principle, federalism requires that power should be divided among layers of government. As the Constitution makes plain, the national government was designed to be one of limited powers, with central responsibilities retained for the states. Beyond these generalities lie deep disagreements about how precisely the federalism principle should be specified and implemented..').

${ }^{15}$ Lopez, 514 U.S. at 551.

${ }^{16} \mathrm{Id}$. at $561 \mathrm{n}$.3 (quoting Brecht v. Abrahamson, 507 U.S. 619, 635 (1993), and United States v. Enmans, 410 U.S. 396, 411-12 (1973)). The Lopez opinion then quoted from President George H.W. Bush's statement issued when he signed the legislation containing the Gun-Free School Zones Act that the law "inappropriately overrides legitimate State firearms laws with a new and unnecessary Federal law." Id. (quoting Statement of President George Bush on Signing the Crime Control Act of 1990, 26 WEEKLY COMP. PRES. DoC. 1944, 1945 (Nov. 29, 1990) (internal quotations omitted)). 
rape. ${ }^{17}$ The cause of action was not predicated on any interstate movement or other direct effect on commerce. ${ }^{18}$ The Court asserted that " $[t]$ he Constitution requires a distinction between what is truly national and what is truly local.... The regulation and punishment of intrastate violence that is not directed at the instrumentalities, channels, or goods involved in interstate commerce has always been the province of the States." 19

The understanding of federalism expressed by the Court in Morrison implied that the Constitution reserves certain subjects to the states to the exclusion of the federal government, in much the same way that it grants specified powers exclusively to the federal government. In this sense, the federal government and the states operate in separate spheres of authority. By declaring statutes adopted pursuant to the commerce power unconstitutional, the Court in Lopez and Morrison signaled the importance of imposing limits on the expansion of federal authority, especially in areas of the criminal law that have long been subject to state and local regulation. Although the commerce power is broad, Lopez and Morrison reiterate the proposition that there is no federal police power, so prosecution of crimes traditionally subject to state and local control may be viewed as violating the limitations on federal authority imposed by federalism.

A federal prosecution involving a state or local official charged with a crime such as bribery raises an additional concern: the propriety of one sovereign's seeking a criminal conviction of a person acting under the auspices of a different sovereign. In other words, do prosecutors representing the federal government invade the province of the states, not only by prosecuting a crime already subject to prosecution by local authorities, but perhaps more importantly, by policing another government's representatives and employees? Invoking federalism as an independent principle to limit the federal government's authority to prosecute public corruption at the state and local level has a superficial appeal..$^{20}$ Lopez and Morrison refer to a seemingly inviolable realm of state authority that appears to include control-perhaps to the exclusion of the federal government-over the prosecution of "local" crimes. The Court's federalism analysis gives the

${ }^{17}$ United States v. Morrison, 529 U.S. 598, 605-08 (2000).

${ }^{18} I d$.

${ }^{19}$ Id. at 617-18 (citations omitted).

${ }^{20}$ See Adam H. Kurland, First Principles of American Federalism and the Nature of Federal Criminal Jurisdiction, 45 EMORY L.J. 1, 6 (1996) [hereinafter Kurland, Federal Criminal Jurisdiction] ("Federal defendants charged with acts of local political corruption often contend that such prosecutions offend federalism and related Tenth Amendment principles."). 
impression of separate spheres of control over criminal law, a scheme that relegates Congress to legislating only in those areas that are obviously "national" in scope.

Lower federal courts are beginning to rely on the Supreme Court's federalism statements in Lopez and Morrison to impose limits on the use of federal statutes to prosecute cases of local corruption. These courts view federalism as a distinct source of constitutional authority permitting them to craft limitations on the application of federal corruption statutes. For example, the Second and Third Circuits cited federalism principles as the basis for interpreting a federal anti-bribery statute to require proof that the corruption of state and local government employees somehow affected the federal interest in the program. ${ }^{21}$ The circuit courts reached this conclusion despite the fact that the terms of the statute clearly did not impose such a requirement for a conviction, and the Supreme Court had seemingly rejected that very reading of the statute in Salinas $v$. United States. ${ }^{22}$ Similarly, a federal district court dismissed an indictment under the same law because the judge believed that a broad interpretation of its scope would violate federalism by "mak[ing] it a federal crime to offer $\$ 20$ to a local traffic cop in order to avoid a $\$ 50$ ticket. ${ }^{, 23}$ A substantial block of dissenting judges in the Fifth Circuit called for a reevaluation of the scope of the Hobbs Act, ${ }^{24}$ one of the principal statutes employed against state and local corruption, arguing that the statute's interstate commerce element is so broad that it reaches local crimes falling beyond the constitutional authority of the federal government. ${ }^{25}$

${ }^{21}$ See United States v. Zwick, 199 F.3d 672, 687 (3d Cir. 1999); United States v. Santopietro, 166 F.3d 88, 93 (2d Cir. 1999).

${ }^{22}$ Salinas v. United States, 522 U.S. 52, 57 (1997) ("The prohibition is not confined to a business or transaction which affects federal funds.").

${ }^{23}$ United States v. McCormack, 31 F. Supp. 2d 176, 183 (D. Mass. 1998) (citing United States v. Apple, 927 F. Supp. 1119,1125 (N.D. Ind. 1996)).

${ }^{24} 18$ U.S.C. $\S 1951$ (a) (2003) ("Whoever in any way or degree obstructs, delays, or affects commerce or the movement of any article or commodity in commerce, by robbery or extortion or attempts or conspires so to do, or commits or threatens physical violence to any person or property in furtherance of a plan or purpose to do anything in violation of this section shall be fined under this title or imprisoned not more than twenty years, or both.").

${ }^{25}$ In United States v. McFarland, 311 F.3d 376 (5th Cir. 2002) (en banc), cert. denied, 155 L. Ed. 515 (2003), the Fifth Circuit divided evenly in affirming Hobbs Act convictions for four robberies of local stores. The dissenting judges asserted that the application of the statute exceeded the commerce power: 
The notion of mutually exclusive spheres advanced in Lopez and Morrison - at least with respect to criminal statutes-overstates the role of federalism in demarcating the authority of the national and state govern-

To allow such aggregation in Lopez category three cases would, without adequate justification, bring within the scope of the Commerce Clause the proscription of local violent (and other) crimes not constituting the regulation of commercial activity, crimes prototypical of those that historically have been within the reserved police power of the states, contrary to the principle that the Commerce Clause is limited to matters that are truly national rather than truly local.

Id. at 409-10. See Kelly D. Miller, Recent Development, The Hobbs Act, the Interstate Commerce Clause, and United States v. McFarland: The Irrational Aggregation of Independent Local Robberies to Sustain Federal Convictions, 76 TUL. L. REV. 1761, 1774 (2002) ("A thorough analysis of the Hobbs Act as it applies to local robberies in light of Morrison should conclude that there is no rational basis for finding that these local robberies substantially affect interstate commerce."). In United States v. Hickman, 179 F.3d 230 (5th Cir. 1999) (en banc), another Fifth Circuit decision affirming Hobbs Act convictions by an equally divided court, the dissenting judges stated, "We believe that the[se] Hobbs Act prosecutions exceeded Congress's authority" because they involved "purely local robberies." Id. at 231 (Higginbotham, J., dissenting). Circuit Judge DeMoss dissented in another Hobbs Act prosecution involving robberies on the ground that "[s]ooner or later the Supreme Court must either back down from the principles enunciated in Lopez or rule that the Hobbs Act cannot be constitutionally applied to local robberies." United States v. Nutall, 180 F.3d 182, 190 (5th Cir. 1999) (DeMoss, J., dissenting). Dissenting judges in the Eleventh Circuit raised a similar concern about the broad application of the Hobbs Act after Lopez, arguing that " $[\mathrm{t}]$ he majority's holding will result in the federalization of any crime involving extortion to acquire money." United States v. Kaplan, 171 F.3d 1351, 1358 (11th Cir. 1999) (en banc) (Birch, J., dissenting). Although these cases all involved robberies, the Hobbs Act uses the same basis - conduct affecting interstate commerce- to assert jurisdiction over public corruption as a form of extortion. See 18 U.S.C. $\$ 1951$ (b)(1) (2000) ("Whoever in any way or degree obstructs, delays, or affects commerce or the movement of any article or commodity in commerce, by robbery or extortion or attempts or conspires so to do, or commits or threatens physical violence to any person or property in furtherance of a plan or purpose to do anything in violation of this section" shall be penalized.). To the extent that the misconduct by a governmental official can be termed "local" rather than "national," defendants and judges can raise the same federalism concerns regarding the application of the statute as the dissenting judges argued in the Hobbs Act cases involving robberies. 
ments. ${ }^{26}$ At least with regard to prosecutions involving corrupt officials, the authority of the federal government to prosecute such crimes advances rather than undermines the principle of federalism. The Constitution reflects the deep concern of the Founders with preventing corruption-what I term the Constitution's "Anti-Corruption Legacy"-a concern that supports congressional power to reach misconduct by officials at all levels of government for the misuse of public authority. ${ }^{27}$

This Article considers the application of federalism to determine the constitutionality of federal statutes used to prosecute corruption of state and local officials. My thesis is that the Anti-Corruption Legacy of the Constitution supports a broad view of the federal government's power to prosecute public corruption at all levels of government. Federal prosecution of corruption does not invade the sovereignty of the states because corruption undermines the balance established by federalism, and the

${ }^{26}$ See Lynn A. Baker \& Ernest A. Young, Federalism and the Double Standard of Judicial Review, 51 DUKE L.J. 75, 87-88 (2001) ("Certainly the graveyard of failed distinctions that these efforts left behind-'commerce' versus 'police' regulation, 'inherently national' versus 'inherently local' matters, 'manufacturing' or 'mining' versus 'commerce,' 'direct' versus 'indirect' effects-does not speak well for the judicial ability to develop doctrinal limits on national power that are at once meaningful and workable."); Roderick M.Hills, Jr., The Political Economy of Cooperative Federalism: Why State Autonomy Makes Sense and "Dual Sovereignty" Doesn't, 96 MiCH. L. REV. 813, 938 (1998) ("[T] he Court has relied ... on palpably untrue statements that the federal and state governments operate in separate, independent, and mutually exclusive spheres ...."); Kurland, Federal Criminal Jurisdiction, supra note 20, at 61 ("[T] he substantive federal criminal law was potentially very broad in scope. It necessarily would overlap with state criminal jurisdiction to varying, and significant, degrees. This much was accepted. So much for a notion of a rigid dual federalism and the demarcation of exclusive spheres of jurisdiction in the criminal law context."); Lawrence Lessig, Translating Federalism: United States v. Lopez, 1995 SUP. CT. REV. 125, 206 ("There is no thing out there called 'tradition' that lower courts can look to to sort out just what objects of regulation should be federal and which local. And because there is nothing out there to guide the courts, courts will be guided to different conclusions."); Ernest A. Young, State Sovereign Immunity and the Future of Federalism, 1999 SUP. CT. REV. 1, 27 ."[E]nclaves of exclusive state authority . . . are exceptionally difficult to sustain because they frequently cverlap with areas in which federal authority is unquestioned.").

${ }^{27}$ See JOHN T. NOONAN, BRIBES 430 (1984) ("In revolutionary ideology, corruption of the legislature by the executive was the way in which the people were deprived of liberty: 'a corrupt and prostituted ministry' was what had sought to 'enslave' Americans. Care to prevent such corruption could scarcely not have been a care of the constitution-makers.") (internal citation omitted). 
national government must protect the integrity of both sides of the federalism equation. The constitutional design to eliminate corruption demonstrates the Framers' intent to guard against the threat to liberty from the misuse of public authority.

The Anti-Corruption Legacy does not provide Congress with the power to adopt legislation, so federal statutes used to prosecute corruption of state and local officials must also be an exercise of one of Congress' enumerated powers. It is important, therefore, first to identify the constitutional basis for provisions used to combat public corruption. In analyzing Congress' constitutional power to enact a statute, the Anti-Corruption Legacy supports a broad interpretation of congressional authority to reach the conduct of state and local officials, regardless of whether the crime could also be prosecuted by the state.

My analysis rejects the position taken by some lower federal courts that federalism limits the authority of Congress or federal prosecutors to target corruption involving state and local officials. The use of federalism to curtail these corruption prosecutions is misguided because the individual liberty afforded by federalism is enhanced when the integrity of government is protected through federal prosecution. If the Constitution's Commerce Clause grants Congress the authority to adopt a statute that can be used to prosecute corruption, then state and local officials charged with corruption should not be empowered to argue that their conduct somehow falls outside the federal government's power because of federalism. ${ }^{28}$ The Supreme Court has rejected some federal statutes that largely duplicate crimes prosecuted by the states, such as the possession of weapons near a school or rape.$^{29}$ Federal prosecutions of state and local officials' corrupt conduct, however, are distinguishable from the Lopez and Morrison prosecutions, not because they do not duplicate state offenses (surely bribery is prohibited under state laws), but instead because public corruption poses a unique threat to the federalist structure by impugning the exercise of public authority. Unlike the Gun-Free School Zones Act and the

${ }^{28}$ See United States v. Gillock, 445 U.S. 360 (1980). Rejecting the defendant's argument that state legislators should be accorded a privilege similar to the U.S. Constitution's Speech or Debate Clause for federal elected officials, the Court held that "[i]n the absence of a constitutional limitation on the power of Congress to make state officials, like all other persons, subject to federal criminal sanctions, we discern no basis ... for a judicially created limitation that handicaps proof of the relevant facts." Id. at 374 .

${ }^{29}$ See supra notes 8-16 and accompanying text (discussing United States v. Lopez, 514 U.S. 549 (1995) and United States v. Morrison, 529 U.S. 598 (2000)). 
Violence Against Women Act, therefore, federal statutes used to prosecute public corruption are not an improper extension of the authority of the national government into affairs reserved to the states. Instead, they are consistent with the structure of the Constitution and a fundamental aspect of the guarantee of liberty embodied in federalism.

Part I of the Article reviews the Anti-Corruption Legacy of the Constitution as support for broad congressional authority to enact legislation to prosecute state and local officials for corruption, even if that corruption does not directly affect the federal government ${ }^{30}$ Part II analyzes the constitutional authority of Congress to adopt the four principal federal statutes used for prosecuting corruption: 18 U.S.C. $\S 201,{ }^{31} 18$ U.S.C. $\S 666,{ }^{32}$ the Hobbs Act, ${ }^{33}$ and the Mail Fraud statute. ${ }^{34}$ I argue that, in light of the Constitution's Anti-Corruption Legacy, these statutes are a proper exercise of Congress' authority to pass laws maintaining the integrity of every level of government. Individual corruption prosecutions should not be prohibited out of a misguided concern that federal prosecution somehow denigrates the sovereignty of the states.

\section{THE ANTI-CORRUPTION LEGACY OF THE CONSTITUTION}

The Constitution reflects a significant concern with preventing corruption in all levels of the government. There is a powerful AntiCorruption Legacy in the Constitution that prevents misuse of federal office for personal gain and, importantly, furnishes protections to limit the effects of corruption occurring in the states. For example, the two crimes mentioned explicitly in the Constitution as forming the basis for impeachment are treason and bribery, both of which involve the abuse of public authority by a federal officer. ${ }^{35}$ The Constitution prohibits the President and members of Congress from taking advantage of their positions to realize economic benefits, at least during their term in office, ${ }^{36}$ and prevents

${ }^{30}$ See infra notes 35-66 and accompanying text.

${ }^{31}$ See infra notes 76-95 and accompanying text.

${ }^{32}$ See infra notes 96-201 and accompanying text.

${ }^{33}$ See infra notes 202-27 and accompanying text.

${ }^{34}$ See infra notes 228-67 and accompanying text.

${ }^{35}$ U.S. CONST. art. II, $\S 4$ ("The President, Vice President and all civil Officers of the United States, shall be removed from Office on Impeachment for, and Conviction of, Treason, Bribery, or other high Crimes and Misdemeanors.").

${ }^{36}$ See U.S. CONST. art. I, § 6, cl. 2 ("No Senator or Representative shall, during the Time for which he was elected, be appointed to any civil office under the authority of the United States, which shall have been created, or the Emoluments 
federal officials from accepting "any present, emolument, office, or title, of any kind whatever, from any king, prince, or foreign state.",37

Beyond concerns with misconduct by federal officials, the Constitution embodies protections against corruption at the state and local level. Article III authorizes federal court jurisdiction in suits between citizens of different states, a scheme which has traditionally been understood as a protection against judicial prejudice in favor of local litigants. ${ }^{38}$ That prejudice was not just a regional bias, but also involved the problem of local control of judicial appointments, which could result in a corrupt outcome in favor of those who appoint judges and provide for their salaries. Similarly, the absence of a right to a jury trial in civil cases was a major stumbling block for proponents of the Constitution during the ratification debates in the states. Although the Constitution guaranteed the right to a jury in criminal cases, the Anti-Federalists sought to extend this right to the civil case context. They argued that the Constitution's failure to provide jury trials in

whereof shall have been encreased during such time; and no Person holding any Office under the United States, shall be a Member of either House during his Continuance in Office."); U.S. CONST. art. II, $\S 1$, cl. 6 ("The President shall, at stated Times, receive for his Services, a Compensation, which shall neither be encreased nor diminished during the Period for which he shall have been elected, and he shall not receive within that Period any other Emolument from the United States, or any of them."). The prohibition in the Congressional Emoluments Clause is one honored more in the breach; NoONAN, supra note 27, at 433 (The prohibition on emoluments was "[a] distinctly modest barrier to corruption of Congress" and "[i]t was to be eventually flouted with impunity by Senator Hugo Black and President Franklin Roosevelt, who appointed Black to the Supreme Court after the Justices' emoluments had been increased while Black was a legislator."); Michael Stokes Paulsen, Is Lloyd Bentsen Unconstitutional?, 46 STAN. L. REV. 907, 908 (1994) (The Congressional Emoluments Clause "is one that people today regard as a nuisance."). The Twenty-Seventh Amendment prohibits members of Congress from accepting a pay raise until after the next election. U.S. CONST. amend. XXVII ("No law, varying the compensation for the services of the Senators and Representatives, shall take effect, until an election of Representatives shall have intervened.").

${ }^{37}$ U.S. CONST. art. I, $\S 9$, cl. 8.

${ }^{38}$ U.S. CONST. art. III, $\S 2$, cl. 1 ("The judicial Power shall extend to all Cases, in Law and Equity, arising under this Constitution, the Laws of the United States, and Treaties made, or which shall be made, under their Authority; - to all Cases affecting Ambassadors, other public Ministers and Consuls; to all Cases of admiralty and maritime Jurisdiction; - to Controversies to which the United States shall be a Party; - to Controversies between two or more States; - between a State and Citizens of another State; - between Citizens of different States ....”). 
civil cases might expose litigants to corrupt outcomes, since a single officer's decision would more likely be biased than would the collective decision of a jury. ${ }^{39}$ Many states provided for juries in civil cases, but the Framers were unable to agree on how to protect the right given the diversity of state procedures. ${ }^{40}$ Ultimately, however, the preservation of the jury trial in some federal civil cases prevailed in the adoption of the Seventh Amendment. ${ }^{41}$

The Anti-Corruption Legacy of the Constitution, like federalism, suggests that a balance between different levels of government will protect the liberty of the people by preventing one level from usurping the authority of the other..$^{42}$ Corruption in any government undermines that balance by permitting individuals to purchase an outcome or by allowing public officials to misuse their authority for personal benefit, resulting in

${ }^{39}$ See The Federalist No. 83 (Alexander Hamilton); see also Matthew P. Harrington, The Economic Origins of the Seventh Amendment, 87 IOWA L. REV. 145,149 (2002) ("The absence of any provision for civil jury trials in the Constitution moved concerns about juries to the forefront of the debate over the future of the new nation. Already suspicious about the scope and breadth of the powers to be given the new government, antifederalists complained that the framers of the Constitution had debased one of the most cherished defenses against governmental oppression.").

${ }^{40}$ See Kenneth S. Klein, The Myth of How to Interpret the Seventh Amendment Right to a Civil Jury Trial, 53 OHIO ST. L.J. 1005, 1014 (1992) ("Ultimately, the Federal Convention's proposed Constitution simply did not speak to civil jury trial rights at all. One recorded comment from the convention reinforces Hamilton's view of why this happened. That comment is from General Pickney (responding to Mr. Gorham), who (according to Madison's notes) argued that given the lack of uniformity of jury practice among the states, a constitutional clause preserving jury rights in civil cases would be 'pregnant with embarrassments.' This comment certainly suggests that the omission of a civil jury clause was intentional and at least in part related to the inability of the delegates to say what the Constitution should require." (quoting 2 THE RECORDS OF THE FEDERAL CONVENTION OF 1787, 628 (Max Farrand ed., 1911)).

${ }^{41}$ U.S. CONST. amend. VII ("In Suits at common law, where the value in controversy shall exceed twenty dollars, the right of trial by jury shall be preserved, and no fact tried by a jury, shall be otherwise reexamined in any Court of the United States, than according to the rules of the common law.").

${ }^{42}$ Cf. United States v. Morrison, 529 U.S. 598, 616 n.7 (2000) ("As we have repeatedly noted, the Framers crafted the federal system of Government so that the people's rights would be secured by the division of power."); Gregory v. Ashcroft, 501 U.S. 452, 458 (1991) ("[A] healthy balance of power between the States and the Federal Government will reduce the risk of tyranny and abuse from either front."). 
considerable social costs. The Constitution embodies the federal government's significant interest in protecting against any form of public corruption, whether at the national, state, or local level. Viewing federal prosecution of state and local officials for corruption as an invasion of state authority would turn the values advanced by federalism on their head. Federalism protects states, and thereby individuals, from oppression by the national government, but it does not permit public authority to be exercised corruptly, harming both the state and its citizenry by insulating non-federal officials from federal criminal prosecution. The Constitution incorporates federalism to enhance the lives of individuals by making government work better-not by permitting some officials to misuse their power. Corruption is not a matter solely of state concern, reserved for the police powers of the states, but is instead a national concern that falls within the interests of the federal government.

\section{A. Corruption and the National Government}

The framers' concern with corruption led to the adoption of a number of provisions in the Constitution limiting the opportunities for selfenrichment. The Constitution provides for the removal of the President and other federal officials by impeachment for "Treason, Bribery, and other high Crimes and Misdemeanors." one draft of the impeachment provision permitted removal of executive branch officers for "neglect of duty, malversation, or corruption." "Another formulation proposed to authorize impeachment for "treason, bribery, or corruption"- - language closer to the final form adopted by the Constitutional Convention. ${ }^{45}$ Arguing in favor of permitting the legislature to impeach the President, Governour Morris asserted that "corruption [and] some few other offences to be such as ought to be impeachable. . .."46 James Madison noted that "[i]n the case of the Executive Magistracy which was to be administered by a single man, loss of capacity or corruption was more within the compass of probable events, and either of them might be fatal to the Republic." 47

${ }^{43}$ U.S. CONST. art. II, $\S 4$.

${ }^{44} 2$ THE RECORDS OF THE FEDERAL CONVENTION OF 1787, supra note 40, at 337.

${ }^{45} \mathrm{Id}$. at 186.

${ }^{46} I d$. at 65 .

${ }^{47} \mathrm{Id}$. at 66 . The first debate on impeachment at the Constitutional Convention centered largely on the propriety of providing a means to remove the President, not on the potential grounds for impeachment. Although the Constitution provides a 
While impeachment permits the removal of officers after the discovery of corruption, other constitutional provisions impose structural protections designed to limit the possibility of corruption in the federal government. The President's compensation "shall neither be encreased nor diminished during the Period for which he shall have been elected, and he shall not receive within that Period any other Emolument from the United States, or any of them." ${ }^{48}$ The Constitution also prohibits anyone holding "any Office of Profit or Trust ... without the Consent of the Congress, [from accepting] any present, Emolument, Office, or Title of any kind whatever, from any King, Prince, or foreign State."49 Members of Congress are subject to a structural provision designed to prevent them from exploiting their offices for personal gain; the Constitution prohibits their appointment to any federal office "which shall have been created, or the Emoluments whereof shall have been encreased during such time" that the member was in office. ${ }^{50}$ The Appropriations Clause ${ }^{51}$ requires congressional authorization before an agency can disburse federal funds, thereby creating a check on the Executive's authority to spend funds that could be used to corrupt the legislature. ${ }^{52}$ These provisions were designed to prevent corruption of federal officers who might be swayed in the execution of their duties by the transfer of a benefit or the incentive to reap a reward related to their

specific definition of treason, see U.S. CONST., art. III, § 3, cl. 1, and empowers Congress to adopt criminal laws on counterfeiting, piracy, and felonies committed on the high seas, see U.S. CONST. art. I, $\S 8$, cls. 6,10 , there is no other reference to bribery beyond its inclusion as a ground for impeachment.

${ }^{48}$ U.S. CONST. art. II, $\S 1$, cl. 6. An emolument is defined as "[a]ny advantage, profit, or gain received as a result of one's employment or one's holding of office." BLACK'S LAW DICTIONARY 542 (7th ed. 1999). The first part of the Emoluments Clause ensures presidential independence from the legislature; in the second part, "[t]he Framers of the Constitution forbade the President from receiving any emolument other than a fixed compensation, in part because they feared the consequences of allowing a President to convert his or her office into a vehicle for personal profit." Griffin v. United States, 935 F. Supp. 1, 3 (D.D.C. 1995).

${ }^{49}$ U.S. CONST. art. I, $\S 9$, cl. 8.

${ }^{50}$ U.S. CONST. art. I, $\S 6$, cl. 2.

${ }^{51}$ U.S. CONST. art. I, $\S 9$, cl. 7 ("No Money shall be drawn from the Treasury, but in Consequence of Appropriations made by Law. ...").

${ }^{52}$ See Adrian Vermeule, The Constitutional Law of Official Compensation, 102 COLUM. L. REV. 501, 509 (2002) ("The Appropriations Clause blocks any symmetrical distribution of compensation authority across branches; its background is the similar concern of seventeenth- and eighteenth-century British Parliaments that an executive with access to the treasury as well as to offices could corrupt legislators and free itself from popular oversight."). 
office. ${ }^{53}$ The prohibitions reach conduct beyond simple bribery because they bar absolutely the receipt of the benefit, regardless of the circumstances. The Constitution's categorical approach to potential corruption goes beyond what any particular criminal law prohibiting bribery or an unlawful gratuity could accomplish.

In addition to the original text of the Constitution, amendments have been adopted in response to corruption, or at least the appearance of corruption. The Seventeenth Amendment, providing for the direct election of senators, resulted from a general perception that elections in the state legislatures were tainted by vote-selling and the control of corrupt local party machines. ${ }^{54}$ Although there was no compelling evidence of widespread corruption in the legislatures, proponents of the Seventeenth Amendment viewed it as a significant means to make the election process less susceptible to the corrosive influence of campaign contributions and other unseemly practices. ${ }^{55}$

The Twenty-Seventh Amendment, approved by Congress with the other amendments in the Bill of Rights in 1789 but not ratified by the states until 1992, prohibits any change in the compensation of members of Congress from taking effect until after the next general election. ${ }^{56}$ The Amendment

${ }^{53}$ See Atkins v. United States, 556 F.2d 1028, 1070 (Ct. Cl. 1977) (noting that the prohibition in Article I, $\S 6$, on members of Congress from holding other offices if they were created or had the salary increased during their term of office "was generated out of a fear that corruption would result if the legislature multiplied the number or increased the salaries of public offices for the benefit of its own members").

${ }^{54}$ See Jay S. Bybee, Ulysses at the Mast: Democracy, Federalism, and the Sirens' Song of the Seventeenth Amendment, 91 Nw. U. L. REV. 500, 538-39 (1997) ("By the early 1890s, as the reform movement gained momentum, there was a general perception that senatorial elections had been bought and sold, that ' $m e n$ have gained seats in the Senate of the United States whom the people of their State would never have chosen to go there, and who never would have gone there but [f]or the corrupt use of money to secure their election.' " (quoting 23 CONG. REC. 6066 (1892) (statement of Rep. Bushnell)).

${ }^{55}$ But see id. at 540 ("The proponents of the Amendment had brought forth evidence of corruption, but they had failed to show that it resulted from the structure of the present mode of election and that structural change in the mode of election would cure the problem.").

${ }^{56}$ U.S. CONST. amend. XXVII ("No law, varying the compensation for the services of the Senators and Representatives, shall take effect, until an election of Representatives shall have intervened."). As one author put it quite well, "This one kind of sneaked up on everybody." Michael Stokes Paulsen, $A$ General Theory of 
anticipated the corruption problems that might result if legislators had the capacity to set their own pay. ${ }^{57}$ The Twenty-Seventh Amendment enhances the risk of electoral defeat if Congress decides to increase its own salary, effectively requiring that a strong case for the increase must be made to the electorate to demonstrate that the higher pay is appropriate. ${ }^{58}$

\section{B. Protection Against Corruption in the States}

The Constitution has direct measures to limit corruption in the national government, but it does not operate directly on the states except through the grant of certain exclusive powers, none dealing specifically with corruption by state officers. The Framers provided certain structural protections, however, to deal with the possibility of corruption or the misuse of authority in the states. The most such protection is the Seventh Amendment's guarantee of a jury trial in specified civil cases, especially those based on diversity jurisdiction, where corruption at the state level would have its greatest effect.

The Constitution did not provide explicitly for jury trials in civil cases-only criminal prosecutions - and the Anti-Federalists attacked the absence of such a guarantee in the ratification debates. ${ }^{59}$ In the Constitutional Convention, Elbridge Gerry argued in favor of a civil jury trial right "to guard [against] corrupt Judges." ${ }^{60}$ Alexander Hamilton conceded that

Article V: The Constitutional Lessons of the Twenty-Seventh Amendment, 103 YALE L.J. 677, 678 (1993).

${ }^{57}$ See Richard B. Bernstein, The Sleeper Wakes: The History and Legacy of the Twenty-Seventh Amendment, 61 FORDHAM L. REV. 497, 501 (1992) ("To the Americans, the ostentatious purchase of Parliamentary seats ... and the often blatant vote-buying attending elections ... exemplified the extraordinary corruption that tainted the British constitutional system... . Guarding against such real or perceived corruption, colonial and state governments early on assumed the responsibility for paying the salaries of their members."); see also Vermeule, supra note 52, at 517 ("Perhaps the Amendment is a redundant safeguard against legislative selfdealing, but well designed systems often contain redundant protections against failures thought sufficiently damaging.").

${ }^{58}$ In proposing the Amendment in the First Congress, Madison stated that "there is a seeming impropriety in leaving any set of men without control to put their hand into the public coffers, to take out money to put in their pockets; there is a seeming indecorum in such power, which leads me to propose a change." 1 ANNALS OF CONG. 457-58 (Joseph Gates ed., 1834).

${ }^{59}$ See supra note 39.

${ }^{60}$ THE RECORDS OF THE FEDERAL CONVENTION OF 1787, supra note 40, at 587. 
there was some benefit in the jury trial while arguing for ratification of the Constitution, stating:

The strongest argument in its favour is, that it is a security against corruption. As there is always more time, and better opportunity, to tamper with a standing body of magistrates, than with a jury summoned for the occasion, there is room to suppose, that a corrupt influence would more easily find its way to the former than to the latter. ${ }^{61}$

The adoption of the Seventh Amendment reflects a concern with possible corruption at the local level, and providing a right to a jury in civil cases limits the effect of that corruption in federal cases.

The jury trial right does not provide any direct protection against corruption in state courts. The Constitution does permit federal courts to hear cases that would otherwise come before state courts when there is diversity jurisdiction between residents of different states, which was another means of protecting individuals against corruption. The usual explanation for the constitutional grant of federal diversity jurisdiction is that it would protect out-of-state litigants against local prejudice by permitting them to bring cases in federal courts, which presumably would not be as susceptible to local pressure. ${ }^{62}$ One reason a federal court could provide a fairer hearing was the protection enjoyed by federal judges of lifetime tenure and undiminished compensation. ${ }^{63}$ The problem does not appear to have been that litigants from outside the state would suffer prejudice solely because of their status as non-residents; instead, drafters feared that local litigants would have greater influence over the judicial appointment process and state courts, therefore, could not necessarily be trusted to view the parties fairly. As noted by Judge Henry Friendly, "[A] careful reading of the arguments of the time will show that the real fear was

${ }^{61}$ The Federalist No. 83, at 434 (Alexander Hamilton) (George W. Carey \& James McClellan eds., 2001). See Charles W. Wolfram, The Constitutional History of the Seventh Amendment, 57 MINN. L. REV. 639, 710 (1973) ("On this ground alone [Hamilton] was prepared to give it a constitutional guarantee, except for the insurmountable problem of drafting a suitable constitutional provision.").

${ }^{62}$ See Charles Alan Wright, Federal CourTs $§ 23$, at 142 (1994) ("The traditional explanation for the creation of diversity jurisdiction is a fear that state courts would be prejudiced against those from out of state.").

${ }^{63}$ U.S. CONST. art. III, $\S 1$ ("The Judges . . shall hold their Offices during good Behaviour, and shall, at stated Times, receive for their Services, a Compensation, which shall not be diminished during their Continuance in Office.”). 
not of state courts so much as of state legislatures." ${ }^{14}$ The method of appointing state judges - specifically the role of the legislatures in seeking to influence the outcome of cases through judicial appointments and salary decisions - meant that local courts could not be counted on to routinely render unbiased decisions. The protections supplied to federal judges limit the possibility of bias because they would be largely free from the pressure to respond to the body that sets their salary and appoints them, or removes them from office. ${ }^{65}$

The protection against corruption provided by diversity jurisdiction and the right to a jury trial is indirect, in that not every litigant could be provided with access to federal courts. Such a result would have been highly problematic, given the suspicions about the authority of the federal courts and the desire of the states to defend their prerogatives. Diversity jurisdiction did not eliminate corruption in the states, but it created a structural means to allow some cases to proceed before a judge who would not be dependent on the state for support. Any judicial officer could be bribed, and the Constitution could do little to prevent that misconduct. The need to insulate the courts from extraneous pressure, and to provide relief in those states that did not, was one impetus for diversity jurisdiction. The Constitution recognized that corruption could have a pervasive impact, so it provided one measure-albeit only an indirect one-to mitigate the potential corruption of state court judges unduly influenced by state legislatures. ${ }^{66}$

${ }^{64}$ Henry J. Friendly, The Historic Basis of Diversity Jurisdiction, 41 HARV. L. REV. 483, 495 (1928); see also Felix Frankfurter, Distribution of Judicial Power Between United States and State Courts, 13 CORNELL L.Q. 499, 520 (1928) ("The real fear was of state legislatures, not of state courts.").

${ }^{65}$ See Friendly, supra note 64, at 497 ("In Connecticut the members of the Council appointed all the judges and then did not hesitate to appear as advocates before them."); John F. Manning, Response, Deriving Rules of Statutory Interpretation from the Constitution, 101 COLUM. L. REV. 1648, 1660-61 (2001) ("Moreover, state legislatures-identified at the time with popular sovereignty-tended to exercise dominion over the courts, whatever the formal assurances proffered by the state constitutions."). Professor Manning reviews how courts in a number of states were subject to indirect legislative control, noting that "[s]tate legislatures sometimes vacated judicial proceedings, granted exemptions from standing law, prescribed the law to be applied to particular controversies, and even decided the merits of cases." Id. at 1661-62.

${ }^{66}$ The Guarantee Clause affords a further protection against corruption and the misuse of authority in the states by providing, "The United States shall guarantee to every State in this Union a Republican Form of Government. . ." U.S. CONST. 
art. IV, $\S 4$. The states could not revert to a monarchy or other type of dictatorial system. The Constitution protects the states from federal interference with the conduct of their affairs so long as they meet the definition of a republican government, but the Guarantee Clause does not provide the states with complete autonomy from federal interference. James Madison described how the Guarantee Clause protected against a broad array of systemic abuses of authority beyond just the form of government in the states: "But who can say what experiments may be produced by the caprice of particular states, by the ambition of enterprising leaders, or by the intrigues and influence of foreign powers?" THE FEDERALIST NO. 43, at 225 (James Madison) (George W. Carey \& James McClellan eds., 2001). Alexander Hamilton noted that the Clause protects the citizenry from "ambition of powerful individuals in single states, who might acquire credit and influence enough, from leaders and favourites, to become the despots of the people..." Id. No. 85, at 453 (Alexander Hamilton) (George W. Carey \& James McClellan eds., 2001). Although the states controlled the means for appointing or electing their leaders, their power was not unfettered because the federal government received the authority to ensure that the states did not abuse their power to such an extent that they violated the rights of individuals or descended into a form of tyranny. See Deborah Jones Merritt, The Guarantee Clause and State Autonomy: Federalism For a Third Century, 88 COLUM. L. REV. 1, 55 (1988) ("The guarantee clause thus demarcates only a modest area of state control over the qualifications of government employees. The clause shields only workers who exercise legislative, executive, or judicial power. Even with respect to these employees, the states may not adopt criteria for selection that violate other constitutional provisions; nor may they retain employees who have violated the constitutional rights of others.").

By permitting a federal role in ensuring the integrity of state governments, the Guarantee Clause reflects the Founders' concern with misuse of authority by the states. True to the principle of federalism limiting the authority of each level of government, the clause protects individual liberty by ensuring that the states do not become completely riddled with corruption. The national government has a very restricted authority to interfere in the administration of the state governments, triggered only by systemic misuse of state authority that undermines the legitimacy of the exercise of official power. The federal concern is that abuse of authority should not reach a level that would result in the destruction of the state government by a tyrannical leader. The Constitution recognizes the national government as the ultimate protector of the citizenry from widespread misuse of authority in the states, perhaps the ultimate form of corruption. See Adam H. Kurland, The Guarantee Clause as a Basis for Federal Prosecutions of State and Local Officials, 62 S. CAL. L. REV. 367, 431 (1989) [hereinafter Kurland, Guarantee Clause] ("[T]he guarantee clause embodies a collective guarantee to the citizenry of republican government. Accordingly; the federal guarantee should extend to combatting state and local corruption because official corruption directly threatens the essential features and the true 'republican' nature of the American governmental system."). 


\section{The Constitutional Grounds \\ FOR FEDERAL ANTI-CORRUPTION STATUTES}

The Constitution's Anti-Corruption Legacy demonstrates that the Founders were concerned with systemic corruption and, to the extent possible in a federal system that permitted the states to retain significant sovereign authority, sought to limit its effects. That Legacy does not, however, provide an independent constitutional grant of authority to the national government to adopt particular legislation to address corruption. The Anti-Corruption Legacy is instructive in interpreting the scope of congressional authority to address corruption at both the federal and state levels. The Constitution bestows on Congress broad power to address the issue, but it is not an unlimited grant of authority to enact any form of legislation to deal with corruption. A criminal statute that authorizes federal prosecution of corruption still must be an exercise of one of the enumerated powers granted to Congress. The Founders' awareness of corruption and their adoption of provisions to limit its effect at both the national and state levels, demonstrate that the use of federal power to attack the misuse of governmental authority by public officials would not be an improper extension of the constitutional power granted to Congress to regulate in specific areas. Fighting corruption is a significant national interest, without regard to the source of the authority abused or the level of government affected by the misconduct.

There is no single federal anti-corruption statute applicable to state and local officials ${ }^{67}$ so prosecutions are brought under a variety of provisions enacted pursuant to different sources of constitutional authority, none of which explicitly authorizes the adoption of criminal statutes. ${ }^{68}$ The Postal Clause $^{69}$ and the Commerce Clause ${ }^{70}$ are authority for the Mail and Wire

${ }^{67}$ There have been efforts in the recent past to adopt a broad federal anticorruption law applicable to all government officials, but Congress has not enacted the legislation. See The Anti-Corruption Act, S. 327, 101st Cong. (1989), reprinted in 135 CONG. REC. 1064. Congress instead relies on a piecemeal approach under which different provisions reach various forms of corruption without providing a single statute targeting corrupt conduct at all levels of government.

${ }^{68}$ Corruption of federal officials is prosecuted under 18 U.S.C. $\S \S 201-209$ (2000), enacted pursuant to the Necessary and Proper Clause, U.S. CONST. art. I, $\S 8, \mathrm{cl}$. 18. Although the federal government must be able to protect itself by prosecuting those who abuse its authority, the Necessary and Proper Clause does not provide Congress with a general police power to adopt criminal laws.

${ }^{69}$ U.S. CONST. art. I, $\S 8$, cl. 7.

${ }^{70} \mathrm{Id}$. at $\mathrm{cl} .3$. 
Fraud statutes, ${ }^{71}$ which reach corrupt schemes involving a breach of fiduciary duty for personal gain. Through an exercise of the Commerce Clause power, the Hobbs Act prohibits the receipt of bribes by any public official. ${ }^{72}$ The source of congressional authority to enact 18 U.S.C. $\S 666^{73}$ to prosecute bribery of officials working in programs or entities that receive more than $\$ 10,000$ in a twelve-month period from the federal government is assumed to be an exercise of the Spending Clause ${ }^{74}$ but the analysis of that source of authority is largely conclusory.

Among the earliest federal criminal statutes was a prohibition on bribing customs officers. This measure served as a means of protecting the principal source of the national government's revenue. Although the Constitution did not grant Congress explicit authority to enact such a prohibition, there is no question that the sovereign can protect itself against the corruption of its officers by enacting criminal penalties for those who offer or take bribes to influence the exercise of authority. ${ }^{75}$

\section{A. Bribery of Public Officials: 18 U.S.C. $\$ 201$}

The most obvious form of corruption is bribery, which involves the offer and receipt of something of value for the purpose of influencing the exercise of authority. ${ }^{76}$ The first federal criminal law prohibited bribery of

718 U.S.C. $\S \S 1341$ (Mail Fraud) \& 1343 (Wire Fraud) (2000).

${ }^{72} I d . \S 1951(\mathrm{~b})(2)$.

${ }^{73}$ Id. $\$ 666$.

${ }^{74}$ U.S. CoNST. art. I, § 8, cl. 1. In Fischer v. United States, 529 U.S. 667 (2000), Justice Thomas asserted in his dissent that $\S 666$ was adopted pursuant to the Spending Clause. See id. at 689.

${ }^{75}$ Even without a statutory basis for the prosecution of corruption, the federal government relied on the common law to indict a defendant for offering a bribe to the Commission of the Revenue, whose office was not covered by the early antibribery laws adopted by Congress. See United States v. Worrall, 2 U.S. (2 Dall.) 384,390 (1798) (holding that criminal statutes prohibit bribery of judges and customs officers, "[b]ut in the case of the Commissioner of the Revenue, the Act constituting the office does not create or declare the offence" of bribery).

${ }^{76}$ See NOONAN, supra note 27, at xi ("The core concept of a bribe is an inducement improperly influencing the performance of a public function meant to be gratuitously exercised."); Daniel Hays Lowenstein, Political Bribery and the Intermediate Theory of Politics, 32 UCLA L. REV. 784, 786 (1985) ("[T]he crime of bribery is the black core of a series of concentric circles representing the degrees of impropriety in official behavior. In this conception, a series of gray circles surround the bribery core, growing progressively lighter as they become more 
customs officers, ${ }^{77}$ and the proscription on bribing federal officials has been a staple of federal law ever since. Congress adopted sections 201 through 218 of Title 18, the primary federal criminal code, in 1962 as part of a set of comprehensive anti-corruption provisions for federal officials and those who exercise federal authority. ${ }^{78}$ The law, inter alia, prohibits bribery of federal employees and of those "acting for or on behalf of the United States ... in any official function." "T9 The statute does not require proof of a jurisdictional element except for the status of the defendant as a "public official." 80 The Supreme Court has noted that $\S 201$ is a proper exercise of the sovereign's inherent authority to protect its functions. ${ }^{81}$ The Necessary and Proper Clause, which provides that Congress may "make all Laws which shall be necessary and proper for carrying into Execution the foregoing Powers," $" 82$ is the constitutional source of authority to enact a

distant from the center, until they blend into the surrounding white area that represents perfectly proper and innocent conduct.").

${ }^{77}$ Act of July 31,1789 , ch. $5, \S 35,1$ Stat. 46-47.

${ }^{78}$ See Pub. L. No. 87-849, 76 Stat. $1119-26$ (1962). The law streamlined a number of anti-corruption and conflict of interest provisions in the federal criminal code into one set of laws. In addition to the prohibition on bribery and unlawful gratuities prohibition, the law prohibited federal officials from receiving payments in addition to their governmental salaries, see 18 U.S.C. $\S 203(2000)$, and restricting former federal officials from appearing before the agency where they worked for a certain period of time, see 18 U.S.C. $\S 207$ (2000).

7918 U.S.C. $\$ 201$ (2000). The act prohibits both bribery and the receipt of unlawful gratuities by any "public official," which is defined as a "Member of Congress, Delegate, or Resident Commissioner, either before or after such official has qualified, or an officer or employee or person acting for or on behalf of the United States, or any department, agency, or branch of Government thereof, including the District of Columbia, in any official function, under or by authority of any such department, agency, or branch of Government . ..."Id. § 201(a)(1). The criminal prohibition applies to every federal employee regardless of whether they are in a supervisory position or exercise discretionary authority. See United States v. Baymon, 312 F.3d 725, 729 (5th Cir. 2002) ("The fact that Baymon [a cook foreman at a federal penitentiary] was a federal employee with official functions is sufficient ... to find he is a public official.").

${ }^{80} 18$ U.S.C. $\S 201$.

${ }^{81}$ See Dixson v. United States, 465 U.S. 482, 500-01 (1984) (In a $\$ 201$ case involving the petitioners' abuse of their authority to allocate federal housing grants by accepting bribes from contractors, the Court found, "The federal government has a strong and legitimate interest in prosecuting petitioners for their misuse of government funds.").

${ }^{82}$ U.S. CONST. art. I, $\S 8$, cl. 18. 
criminal law punishing misuse of federal authority. Although that provision does not usually constitute a separate grant of power to Congress to adopt a law, ${ }^{83}$ the Clause empowers Congress to go beyond the text of the enumerated powers by adopting regulations - including criminal statutesthat are a necessary concomitant to the exercise of its sovereign authority. ${ }^{84}$

An anti-corruption statute enacted to punish those who seek to pervert the exercise of federal authority through the offer and receipt of a bribe is certainly a reasonable exercise of the federal government's authority. Nevertheless, there is no textual authority for Congress to adopt such a statute, although the federal courts have enforced similar proscriptions since the formation of the United States. ${ }^{85}$

The increasing number of state and local programs funded, at least in part, by the federal government in the 1970s raised the question of whether $\S 201$ could be used to police corruption at the local level. In Dixson $v$. United States,${ }^{86}$ the defendants challenged their convictions under $\S 201$ for accepting bribes related to the defendants' distribution of federal funds to a local social service organization designated to administer federal block grants for housing. The defendants were officials of a local organization funded by the federal government, but they were neither employees of the federal government nor parties to any contract with it. The Supreme Court rejected the argument that the defendants fell outside the jurisdictional boundaries of $\S 201$, holding that they could be prosecuted under the law because a "public official" includes any person who "occupies a position

${ }^{83}$ See Gary Lawson \& Patricia B. Granger, The "Proper" Scope of Federal Power: A Jurisdictional Interpretation of the Sweeping Clause, 43 DUKE L.J. 267, 274-75 (1993) ("An exercise of the Sweeping Clause power must always be tied to the exercise of some other identifiable constitutional power of the national government.").

${ }^{84}$ Chief Justice Marshall's seminal analysis of the Necessary and Proper Clause in M'Culloch v. Maryland, 17 U.S. (4 Wheat.) 316 (1819), relied on federal criminal laws as a paradigmatic example of the type of congressional acts authorized by the Constitution even though the enumerated powers do not specifically authorize them. "So, with respect to the whole penal code of the United States: whence arises the power to punish, in cases not prescribed by the constitution?" Id. at 416. The answer was the Necessary and Proper Clause. See JOHN E. NowAK \& RonALD D. RotUNDA, CONSTITUTIONAL LAW $\S 3.2$ (6th ed. 2000) ("Because the framers intended the nation to endure, the federal government had to have the normal discretionary powers of a sovereign so that Congress could choose how to best effectuate national goals.").

${ }^{85}$ See, e.g., United States v. Worrall, 2 U.S. (2 Dall.) 384 (1798) (receiving a prosecution for attempted bribery of the Commissioner of Revenue).

${ }^{86}$ Dixson, 465 U.S. at 482. 
of public trust with official federal responsibilities," regardless of whether there was an employment or other direct agency relationship. ${ }^{87}$ The Court noted that the statute required proof that the defendant actually carried out federal policy, although merely administering a program that received some federal funds, standing alone, would not establish that a person was a "public official" under $\S 201 .^{88}$

Justice O'Connor dissented from the Court's broad reading of "public official" on the ground that federalism imposed a separate limit on the scope of the statute. She argued that "[a] proper respect for the sovereignty of States requires that federal programs not be interpreted to deputize States or their political subdivisions to act on behalf of the United States unless such deputy status is expressly accepted or, where lawful, expressly imposed." ${ }^{89}$ This dissent was the first mention of federalism as a potential limit on the authority of the federal government to reach corruption at the state and local level, and it hinted that federalism might impose a limit on federal power separate from the question of the statute's jurisdictional reach..$^{90}$

Dixson shows that the national government's authority to prosecute corruption is not limited to those defendants who have a formal employment relationship with the federal government; the federal government may punish state or local corruption that threatens the integrity of specific federal programs. ${ }^{91}$ Extending $\S 201$ to cover the conduct of local officials

${ }^{87} I d$. at 496 . The Court noted with approval that "[f]ederal courts interpreting the federal bribery laws prior to 1962 had generally avoided formal distinctions, such as the requirement of a direct contractual bond, that would artificially narrow the scope of federal criminal jurisdiction." Id. at 494.

${ }^{88}$ Id. at 499 ("[W]e do not mean to suggest that the mere presence of some federal assistance brings a local organization and its employees within the jurisdiction of the federal bribery statute or even that all employees of local organizations responsible for administering federal grant programs are public officials within the meaning of section 201(a).").

${ }^{89} \mathrm{Id}$. at 510 (O'Connor, J., dissenting).

90 Justice O'Connor's discussion of federalism expressed a position later adopted by the Supreme Court in New York v. United States, 505 U.S. 144 (1992), and Printz v. United States, 521 U.S. 898 (1997), prohibiting Congress from directly compelling the states to implement a federal policy. The Court reasoned that Congress violates states' sovereignty when it acts directly on the states to require them to engage in certain conduct.

${ }^{91}$ The Court has not always defined "public official" so broadly for the purpose of federal bribery statutes. In Krichman v. United States, 256 U.S. 363 (1921), the Court overturned the federal bribery conviction of a baggage porter at a railroad station who took a payment to expedite delivery of a trunk, even though the railroad 
who administer federal programs was not an affront to federalism because the federal statute did not commandeer state or local officials to do its bidding or otherwise usurp the state's authority to administer its policies, as Justice O'Connor argued it did. Dixson permits the federal government to punish those who misuse federal authority, even where the government funnels that power through a local or non-governmental agency. The federal government's interest remains the same in protecting against the misuse of its sovereign power, and the criminal prohibition works no greater invasion of the authority of the states than does the creation of federally funded programs that use local officials to carry out federal policy. $^{92}$

Justice O'Connor's reference to federalism was the first hint that some members of the Court viewed federalism as a potential limit on the scope of congressional authority to regulate through criminal statutes. Although the Court decided Dixson ten years before Lopez, the question of whether

was under the control of the United States during World War I and therefore the porter technically was an employee of the United States. The statute under which the petitioner was convicted, 18 U.S.C. $\S 91$, required that the person prosecuted be "an officer of the United States, or . . . a person acting for or on behalf of the United States ..." Id. at 365. The Court stated that "[n]ot every person performing any service for the government, however humble, is embraced within the terms of the statute. It includes those, not officers, who are performing duties of an official character." Id. at 366 . The Court found that the bribery, which was little more than an otherwise unremarkable tip except for the nationalization of the rails during the war, was beyond the intent of Congress because the statute would sweep up every employee of the United States. Id. Krichman seems to be more a visceral reaction to prosecutorial unfairness in seeking to criminalize an everyday event-a porter's accepting a tip for carrying a bag - than a principled limitation on the scope of the bribery provision. $C f$. United States v. Baymon, 312 F.3d 725, 729 (5th Cir. 2002) (upholding conviction under $\S 201$ of a prison cook because "the fact that he violated rules of employment as a federal employee by accepting a thing of value in exchange for smuggling in contraband and was therefore released from his employment is sufficient factual support ... that he had responsibilities which he did not keep").

${ }^{92}$ In Reno v. Condon, 528 U.S. 141 (2000), the Court upheld the Driver's Privacy Protection Act, which restricted the states from disclosing driver's license information. Although the statute directly regulated the states, the Court found that the statute was a valid exercise under the Commerce Clause and did not violate federalism because it did "not require the States in their sovereign capacity to regulate their own citizens." Id. at 142 . Criminal laws— such as $\S 201$-nforced by the federal government do not even involve the use of state and local officials to implement a federal policy. 
federalism limits how Congress can regulate would come up again. Section 201 , however, remains largely uncontroversial because bribery in the exercise of any official authority subverts the governmental process, and the federal interest in prosecuting such misconduct is significant.

The federal government is not limited to policing its own officials and programs because the constitutional authority to regulate includes the power to prescribe the use of interstate commerce and to spend federal funds to further national interests. Congress enacted two statutes that apply directly to the corruption of state and local officials who may fall outside the prohibitions of $\S 201$. The Hobbs Act prohibits extortion committed "under color of official right,"93 and 18 U.S.C. $\S 666$ prohibits bribery of an officer of any organization or state or local government that receives benefits in excess of $\$ 10,000$ from the federal government during a oneyear period. ${ }^{94}$ Both provisions reach corruption by those who are not employees of the federal government and who do not have specific federal responsibilities. ${ }^{95}$ These provisions are a significant extension of federal authority beyond the protection of the functions of the sovereign that permitted Congress to adopt $\S 201$ as an exercise of its inherent authority under the Necessary and Proper Clause. The issue of federalism arises in connection with ascertaining the scope of congressional authority to adopt criminal statutes under these broader constitutional grants.

\section{B. Federal Prosecution of Local Corruption: 18 U.S.C. $\$ 666$}

Section 666 is a broad federal anti-corruption statute aimed explicitly at corruption at the state and local levels, including private organizations that receive federal funds. Congress adopted the provision in 1984 out of fear that a narrow interpretation of $\S 201$ by the Supreme Court in Dixson would effectively exempt virtually all non-federal officers from prosecution under the anti-corruption statute. Congress expressed the concern that a narrow interpretation of $\S 201$ 's applicability to non-governmental officials involved in the administration of federal programs and grants "gives rise to a serious gap in the law, since even though title to the monies may have

${ }^{93} 18$ U.S.C. $\S 1951(\mathrm{~b})(2)(2000)$.

${ }^{94}$ Id. $\S 666(\mathrm{~b})$.

${ }^{95}$ See NoRman ABRAMS \& SARA Sun BEALE, FEdERAL Criminal LaW AND ITS ENFORCEMENT 195 (3d ed. 2000) ("Because the federal bribery and gratuities laws apply only to federal officials, (or state and local officials receiving federal funds) federal prosecutions of state and local cornuption must be brought under some other provision."). 
passed, the federal government clearly retains a strong interest in assuring the integrity of such program funds." augment "the ability of the United States to vindicate significant acts of theft, fraud, and bribery involving federal monies that are disbursed to private organizations or state and local governments pursuant to a federal program."97

While the Hobbs Act utilizes the broadest extent of the federal power under the Commerce Clause, it has a more limited application than $\S 666$ because it reaches only the public official receiving a payment-who extorts under color of official right - and not the offeror. Congress adopted $\S 666$ to broaden the scope of federal anti-corruption law by permitting the prosecution of those who make corrupt payments, and by prohibiting other forms of corruption such as embezzlement, theft, and fraud from governmental organizations. Unlike $\S 201$, which reaches only federal employees and those who exercise federal authority, $\$ 666$ applies to any "agent of an organization, or of a State, local, or Indian tribal government, or any agency thereof . . . .98 Instead of limiting the statute to those occupying specific official positions, $\S 666$ conditions federal jurisdiction on the requirement that the defendant be an agent of an "organization, government, or agency [that] receives, in any one year period, benefits in excess of $\$ 10,000$ under a Federal program involving a grant, contract, subsidy, loan, guarantee, insurance, or other form of Federal assistance." 99 The statute also limits federal jurisdiction by requiring proof that the bribe occur in connection with transactions of the agency or governmental unit with a value of $\$ 5000$ or more. ${ }^{100}$ The corrupt payment itself need not have any specific value - the statute only requires the offer and acceptance of "anything of value" - but the subject matter of the corruption must meet the $\$ 5000$ threshold for federal jurisdiction.

Section 666 is a logical extension of the federal interest in combating corruption, an interest recognized by the Supreme Court in Oklahoma $v$.

${ }^{96}$ S. REP. NO. 98-225, at 369 (1983), reprinted in 1984 U.S.C.C.A.N. 3182 , 3510. The Senate Report specifically discussed—and sought to mitigate the effect of the Second Circuit's decision in United States v. Del Toro, 513 F.2d $656(2 \mathrm{~d}$ Cir. 1975), which read $\S 201$ narrowly so that it did not cover state and local officials. See S. REP. No. 98-225, at 370 . The Supreme Court's broad reading of "public official" in Dixson largely undermined those narrow interpretations of $\S$ 201. See United States v. Dixson, 465 U.S. 482 (1984).

${ }^{97}$ S. REP. NO. 98-225, at 369, reprinted in 1984 U.S.S.C.A.N. 3182, 3510.

${ }^{98} 18$ U.S.C. $\$ 666(\mathrm{a})(1)(2000)$.

${ }^{99} I d . \S 666(\mathrm{~b})$.

${ }^{100} I d . \S 666(\mathrm{a})(1)(\mathrm{B})$. 
United States Civil Service Commission. ${ }^{101}$ The Court upheld the authority of the federal government to impose conditions on states that accept federal funds even though the condition was designed to reduce corruption in state and local government, not the national government. The federal law at issue prohibited any "officer or employee of any State or local agency whose principal employment is in connection with any activity which is financed in whole or in part by loans or grants made by the United States or by any Federal agency ... [from] tak [ing] any active part in political management or in political campaigns." 102 Although Congress did not have the constitutional authority to impose the requirement directly on the states, it could attach conditions to the states' receipt of federal benefits "by requiring those who administer funds for national needs to abstain from active political partisanship." 103 The federal government's interest in eliminating corruption from all levels of government does not undermine the authority of the states, but rather enhances the integrity of all governments. ${ }^{104}$

${ }^{101}$ Oklahoma v. United States Civil Serv. Comm'n, 330 U.S. 127 (1947).

${ }^{102}$ Id. at 129 (citing 18 U.S.C. $\$ 61$ ). The provision at issue in Civil Service Commission, though found to be constitutional, was subsequently amended. Today, the Hatch Act, 5 U.S.C. $§ 1502$ (2000), provides:

(a) A State or local officer or employee may not-

(1) use his official authority or influence for the purpose of interfering with or affecting the result of an election or a nomination for office;

(2) directly or indirectly coerce, attempt to coerce, command, or advise a State or local officer or employee to pay, lend, or contribute anything of value to a party, committee, organization, agency, or person for political purposes; or

(3) be a candidate for elective office.

(b) A State or local officer or employee retains the right to vote as he chooses and to express his opinions on political subjects and candidates.

(c) Subsection (a)(3) of this section does not apply to-

(1) the Governor or Lieutenant Governor of a State or an individual authorized by law to act as Governor;

(2) the mayor of a city;

(3) a duly elected head of an executive department of a State or municipality who is not classified under a State or municipal merit or civil-service system; or

(4) an individual holding elective office.

${ }^{103}$ Civil Serv. Comm'n, 330 U.S. at 143.

${ }^{104}$ See George D. Brown, Stealth Statute-Corruption, the Spending Power, and the Rise of 18 U.S.C. $\$ 666,73$ NOTRE DAME L. REV. 247, 272 (1998) [hereinafter Brown, Stealth Statute] ("It is possible, then, to read Oklahoma for the 
Since Lopez, however, courts have raised federalism questions about the propriety of federal prosecution of state and local officials under $\S 666$ to reach corruption in public offices and programs receiving federal assistance. Some lower courts have criticized the breadth of $\S 666$ because it permits the federal government to prosecute state and local officials. These courts perceive the statute as offending the principles of federalism and have therefore imposed limits on its scope. These efforts, however, ignore the clear language of the statute, which permits the prosecution of corruption in state and local governments when the conduct is sufficiently serious to warrant federal intervention. Federalism does not give courts independent authority to rewrite statutes, and in the field of public corruption the Anti-Corruption Legacy of the Constitution supports congressional authority to adopt a broad statute targeting misconduct in the administration of state and local government.

\section{Salinas and Fischer:}

The Broad Reading of Federal Authority under $\$ 666$

The Supreme Court has interpreted $\S 666$ broadly on two occasions, rejecting arguments that would have limited the authority of the federal government to prosecute local corruption. In Salinas $v$. United States, ${ }^{105}$ the defendant was a deputy sheriff convicted of accepting bribes from a federal prisoner, housed in the county jail, in exchange for preferential treatment toward the prisoner. ${ }^{106}$ The amount of federal funds received by the jail easily exceeded the statutory $\$ 10,000$ minimum, and the transactions that were the subject of the bribe had a value greater than $\$ 5,000$, so the jurisdictional elements were undisputed. The Court rejected the defendant's argument that, to prove jurisdiction under the statute, the government must prove that the subject matter of the bribe involved the federal funds provided to the agency or government: "The prohibition is not confined to a business or transaction which affects federal funds. The word 'any,' which prefaces the business or transaction clause, undercuts the attempt to impose this narrowing construction." 107 The Court recognized that Congress adopted $\S 666$ to expand federal anti-corruption law, so restricting the

proposition that Congress can utilize a state or local government's receipt of federal funds as a hook to impose the 'broad policy objective' of honest pubic services upon that government.").

${ }^{105}$ Salinas v. United States, 522 U.S. 52 (1997).

${ }^{106} \mathrm{Id}$. at 52.

${ }^{107}$ Id. at 57. 
statute to only bribes that directly affect the federal funds "would be incongruous ...." ${ }^{108}$ The Court also rejected the defendant's federalism argument, based on Gregory $v$. Ashcroft, that the statute implicitly required a nexus between the alleged misconduct and federal funds because it did not plainly state the contrary. ${ }^{109}$

Although the Court found the statute unambiguous, it further asserted "there is no serious doubt about the constitutionality of $\S 666(\mathrm{a})(1)(\mathrm{B})$ as applied to the facts of this case." ${ }^{110}$ It is not clear why the Court saw a need to address further the constitutionality of the provision, especially if there was "no serious doubt" on an issue that was not relevant to the statutory analysis and outside the question presented by the defendant. Despite its holding that the government need not show a connection between the bribe and the federal funds, the Court referred obliquely to federalism, stating that "[w] hatever might be said about $\S 666(a)(1)(B)$ 's application in other cases, the application of $\S 666(\mathrm{a})(1)(\mathrm{B})$ to Salinas did not extend federal power beyond its proper bounds." 111

The constitutionality of $\S 666$ under federalism is a question of congressional authority to regulate, not the propriety of an application of a statute in a particular prosecution. Salinas' off-hand reference to the constitutionality of the statute "as applied" misstated the proper constitutional analysis by giving the impression that federalism might require additional proof of some relationship between the federal interest and a defendant's conduct beyond the elements contained in the statute. ${ }^{112}$ The majority in Salinas may have been trying to assuage fears that $\S 666$ created a crime wholly outside the federal interest, but the Court's vague invocation of federalism had the effect of encouraging lower courts to consider arguments that the Constitution requires an extra-statutory limit on the application of the statute.

The Court's second decision construing $\S 666$ was Fischer v. United States ${ }^{113}$ which broadly read the term "benefits" in determining whether an organization or agency meets the $\$ 10,000$ federal benefits element. At trial, the defendant was convicted of violating $\S 666$ for defrauding a hospital

${ }^{108} \mathrm{Id}$. at 58 .

${ }^{109}$ Id. at 60 .

${ }^{110}$ Id. (emphasis added).

${ }^{111} I d$. at 61 .

${ }^{112}$ Cf. United States v. Lipscomb, 299 F.3d 303, $311-12$ (5th Cir. 2002) ("The Court nonetheless obliquely suggested [in Salinas] that there might be obstacles to applying $\S 666$ to different facts ....").

${ }^{113}$ Fischer v. United States, 529 U.S. 667 (2000). 
authority that received funds under the Medicare program and for paying a kickback to an officer of an organization receiving federal funds. ${ }^{114}$ Both the Eleventh Circuit and the U.S. Supreme Court affirmed the convictions. Whether a government payment constitutes a "benefit" under $\S 666$, the Supreme Court held, depends on an examination of the program's "nature and purposes." 115 The Court rejected the defendant's argument that Medicare funds are only a reimbursement to the hospital for services provided to the ultimate beneficiaries, finding instead that the funds "are made not simply to reimburse for treatment of qualifying patients but to assist the hospital in making available and maintaining a certain level and quality of medical care, all in the interest of both the hospital and the greater community."116

Although Fischer construed the statutory term broadly, the Court noted that the receipt of funds from the federal government would not automatically constitute a "benefit" because that "would turn almost every act of fraud or bribery into a federal offense, upsetting the proper federal balance." "117 The Court did not explain what it meant by the "proper federal balance," but like Salinas, the opinion may have sought to assuage any apprehension that the statute would permit the federal government to prosecute crimes for which there was no clear federal interest. ${ }^{118}$ The Court never explained what the federalism limits were for offenses involving corruption in programs receiving federal funds. Unlike $\S 201$, which only reaches federal officials and those actually exercising federal authority, $\S 666$ applies to all public officials and private persons working for organizations or programs that receive substantial federal funding. The

${ }^{114} \mathrm{Id}$. at 670 . The charges related to a $\$ 1.2$ million loan from the West Volusia Hospital Authority-which received between $\$ 10$ and $\$ 15$ million in Medicare funds-to defendant's company, and a $\$ 10,000$ payment from the loan proceeds to the Hospital Authority's chief financial officer. Id.

${ }^{115} \mathrm{Id}$. at 671 .

${ }^{116} \mathrm{Id}$. at 679-80.

${ }^{117}$ Id. at 681 .

${ }^{118}$ See United States v. Lipscomb, 299 F.3d 303, 313 (5th Cir. 2002) ("The Salinas Court merely observed in passing that, even if a federal interest were required, such an interest clearly existed.... Similarly, the Fischer Court construed a term in $\S 666$ broadly, simply musing that federalism principles might somehow limit the statute's sweep. As either a statutory or constitutional matter, then, the Court might be seen as harboring inchoate qualms about whether, for $\S 666$ to apply, there might be some need for a direct interest in the funds involved in the prohibited conduct. ..." (emphasis added)). 
statute does not condition federal jurisdiction on the source of authority or on a direct connection between the office and the federal funds.

Federal anti-corruption law reaches beyond those directly employed by state and local governments, so there is a legitimate concern that not every act in the private sector that may be corrupt should be prosecuted under $\S 666$ if a transfer of federal funds to the organization could be found. Fischer described the animating principle behind $\S 666$ as protecting from corruption the "integrity" of programs that receive federal funds-not just protecting the funds themselves. ${ }^{119}$ Section 666 permits the federal government to act against both public and private corruption to the extent that official authority or a substantial governmental policy is involved in the program or organization; this involvement may be evidenced by the receipt of a substantial amount of federal funds. The "proper federal balance" includes protecting citizens from corruption by those purportedly acting in the public interest, regardless of the states' authority to prosecute such offenses.

\section{Creating an Extra-Statutory Limit on Prosecutions under $\S 666$}

Despite the broad readings of $\S 666$ in Salinas and Fischer, some lower courts focused on the vague references to federalism in the Supreme Court's opinions as a suggestion that they have the authority to impose a limit on the statute to protect its constitutionality. Although the provision does not require that the corrupt acts directly affect the receipt or administration of federal money, some courts adopted a limited reading of the statute, requiring the government to establish some federal nexus_albeit something short of the direct effect on the funds that Salinas rejected-between the corruption and the federal role in the program or organization, in order to avoid what they perceived to be potential constitutional problems with the statute.

In United States $v$. Zwick, ${ }^{120}$ the Third Circuit held that the prosecution must prove a federal interest in the defendant's conduct, but the extent of

119 See Fischer, 529 U.S. at 681 ("The Government has a legitimate and significant interest in prohibiting financial fraud or acts of bribery being perpetrated upon Medicare providers. Fraudulent acts threaten the program's integrity."); see also S. REP. No. 98-225, at 370 (1983), reprinted in 1984 U.S.C.C.A.N. 3182 , 3511 (The purpose of $\S 666$ is "to protect the integrity of the vast sums of money distributed through federal programs from theft, fraud, and undue influence by bribery.").

${ }^{120}$ United States v. Zwick, 199 F.3d 672 (3d Cir. 1999). 
that relationship was unclear because "we surmise that a highly attenuated implication of a federal interest will suffice for purposes of $\S 666 . " 121$ The defendant was a member of a Pennsylvania township's Board of Commissioners who solicited small-scale bribes from local businesses. ${ }^{122}$ The government introduced proof that the township received federal funds for emergency snow removal and a stream erosion project, which the court found insufficient for a federal prosecution because the funds "bear no obvious connection to Zwick's offense conduct, which involved sewer access, use permits and landscaping performance bonds." 123

The Second Circuit adopted a similar interpretation of $\$ 666$ in United States $v$. Santopietro, ${ }^{124}$ holding that the government must demonstrate "at least some connection between the bribe and a risk to the integrity of the federal[ly] funded program ...."125 The court noted that its earlier position

${ }^{121}$ Id. at 687.

${ }^{122} \mathrm{Id}$. at $676-77$.

${ }^{123}$ Id. at 688 . The Third Circuit vacated the conviction and remanded for a new trial, in part because the district court did not require the government to present proof of the relation between the federal funds and the defendant's conduct, the new element of the offense created by the circuit court's holding. Id.

The vague connection requirement imposed by $Z$ wick requires the fact-finder to trace the funds from a federal program to the organization involved in the misconduct, and to determine whether the funds were sufficiently related to the alleged corruption to permit the prosecution to proceed. These facts may not be apparent until after trial. In United States v. Wright, 206 F. Supp. 2 d 609 (D. Del. 2002), the district court painstakingly analyzed the government's evidence and reversed the defendant's conviction, holding that "[w]hile the federal government gives funds to [Delaware Department of Transportation] projects, as it likely gives to all the Departments of Transportation of all states, that does not in and of itself create a federal interest in briberies that are unrelated to the projects that it funds." Id. at 625 . Tracing the federal funds through various state and local offices is exactly the opposite of what $\S 666$ requires; Salinas rejected the argument that the government must show where the funds went or their relation to the corruption. Yet, the vague connection requirement imposed by Zwick and other decisions has the same effect, because trial courts will have to look to the flow of funds to find the connection. The government may have to guess at how much evidence will be necessary to meet the federal connection condition-the circuit courts have deliberately left this question unanswered to avoid the Supreme Court's rejection of a direct nexus requirement for a conviction - and likely will err on the side of overproducing information to avoid losing a conviction on a ground unrelated to the corruption at issue.

${ }^{124}$ United States v. Santopietro, 166 F.3d 88 (2d Cir. 1999).

${ }^{125} \mathrm{Id}$. at 93. 
requiring proof that the corruption affected the federal funds was no longer viable after Salinas, "but nothing in Salinas disturbs" its requirement that the government prove "some connection" to the federal funds, despite the fact that the statute contains no such element. ${ }^{126}$

In United States v. McCormack, ${ }^{127}$ a district court dismissed the indictment of a police officer for accepting a $\$ 4000$ bribe, finding that $\S 666$ must be limited to conduct that bears some relationship to the federal expenditure. ${ }^{128}$ The district court found that federalism limited the authority

${ }^{126}$ Id. The Second Circuit's decision in United States v. Foley, 73 F.3d 484 (2d Cir. 1994), had required the government to prove that the corruption "in some way ... touch upon federal funds." Id. at 493. In United States v. Kranovich, 244 F. Supp. 2d 1109 (D. Nev. 2003), the United States District Court for the District of Nevada relied on the Second and Third Circuit decisions in holding that "[w]hile there is no definitive answer to this question, we are persuaded that proof of a link between the federal funds and the theft or bribe is necessary" for a $\S 666$ charge. Id. at 1115 .

The Fifth Circuit has struggled over the issue of how closely related the corruption must be to the federal funding. In United States v. Phillips, 219 F.3d 404 (5th Cir. 2000), the Fifth Circuit overturned a conviction under $\S 666$ because the defendant was not an agent of the entity that received the federal funds, and therefore his "actions did not and could not have threatened the integrity of federal funds or programs." Id. at 413 . The Fifth Circuit noted that its requirement that the defendant be an agent of the particular organization receiving the federal funds was "in close parallel" with the requirement "that the recipient organization must be affected by the fraud." Id. at 413 n.14. Phillips did not impose a federal nexus requirement, similar to Zwick and Santopietro, however, and a later Fifth Circuit opinion recognized that the relationship between the federal funds and the program in which the corruption occurred need not be close. See United States v. Reyes, 239 F.3d 722, 735 (5th Cir. 2001) ("We are not convinced that Salinas wrought a change upon our earlier precedents" rejecting a nexus requirement.). In United States v. Lipscomb, 299 F.3d 303 (5th Cir. 2002), a panel of Fifth Circuit judges splintered over the constitutionality of $\S 666$ in a case involving a former member of the Dallas City Council, with each judge issuing a separate opinion. Two judges decided to uphold the conviction for completely different reasons. Judge Smith argued that the application of the statute was unconstitutional as applied because there was no federal interest affected by the defendant's corrupt conduct. See id. at 372 (Smith, J., dissenting) ("'I]t cannot be necessary and proper to executing the spending power for the government to prosecute local crimes that have no relationship whatsoever to federal funds and programs.").

${ }^{127}$ United States v. McCormack, 31 F. Supp. 2d 176 (D. Mass. 1998).

${ }^{128} \mathrm{Id}$. at 189. 
of the federal government to prosecute a local official for a violation already covered by state criminal law. ${ }^{129}$ Relying on Lopez, it held that "whatever other applications of $\S 666$ may be constitutional, this one is not." 130 The district court in McCormack was troubled by the application of a federal statute to what the court viewed as a matter of petty corruption, noting at one point that under a broad interpretation of the statute, "[T]he law could make it a federal crime to offer $\$ 20$ to a local traffic cop in order to avoid a $\$ 50$ ticket." ${ }^{131}$ It concluded that the prosecution was unconstitutional because the case involved only local corruption unrelated to the federal government's interests. ${ }^{132}$

The Sixth, Seventh, and Eighth Circuits rejected arguments that, under $\S 666$, the government must prove some relationship between the federal funds that meet the statutory requirement and the defendant's corruption. ${ }^{133}$ The Eighth Circuit held that "other than the threshold showing that the agency in question received more than $\$ 10,000$ in federal benefits in any

${ }^{129} I d$. at 185 .

${ }^{130} \mathrm{Id}$. at 187.

${ }^{131}$ Id. at 183 (citing United States v. Apple, 927 F. Supp. 1119, 1125 (N.D. Ind. 1996)).

${ }^{132}$ Id. at 189 ("Clearly the conduct at issue here-bribing a local police officer to prevent further investigation and/or prosecution for state crimes-is not 'related to a legitimate national problem' because it is not directed towards protecting the integrity of federal funds given to the Malden police department or even to the programs those funds were intended to support."). The district court was not required to reach the constitutional issue, because it found that the $\$ 4000$ bribe did not meet $\S 666$ 's requirement that the corrupt payment be in connection with transactions involving a value of $\$ 5000$ or more (the court reasoned that the bribe affected conduct with only an intangible value, not a monetary value). See id. at 182-83. It is not clear why the district court addressed the constitutional question after finding that the government had not charged a crime under $\S 666$ because it could not establish all the elements of the offense. The court did not even assert that its constitutional analysis was an alternative holding, or that the constitutional issue affected its analysis of the government's proof. Id. at 189.

Similarly to the McCormack court, the district court in United States v. Frega, 933 F. Supp. 1536 (S.D. Cal. 1996), dismissed $\S 666$ charges on the ground that "the indictment does not allege that federal funds were corruptly administered, were in danger of being corruptly administered, or even could have been corruptly administered." Id. at 1543. In United States v. Kranovich, 244 F. Supp. $2 \mathrm{~d} 1109$ (D. Nev. 2003), a district court adopted the nexus requirement but then held that the government's proof at trial established that additional requirement.

${ }^{133}$ See United States v. Sabri, 326 F.3d 937 (8th Cir.), cert. granted, 124 S. Ct. 387 (2003); United States v. Dakota, 188 F.3d 663, amended, 197 F.3d 821 (6th Cir. 1999); United States v. Grossi, 143 F.3d 348 (7th Cir. 1998). 
one-year period, § 666 imposes no requirement that there be a connection between the offense conduct and the federal funds." ${ }^{134}$ Although the Sixth Circuit rejected the nexus element, a panel of the court noted that "[w]ere we writing on a clean slate, I, like the dissent, might well agree that proper application of 18 U.S.C. $\S 666$ requires a minimal nexus between the alleged criminal activity and the federal funding received pursuant to the statute." 135

Decisions requiring the government to prove this funding-corruption nexus relied on assertions in Salinas and Fischer. Although the Court construed $\S 666$ broadly in those cases, it stated that it had avoided even more expansive readings of the statute that, while plausible, might upset the "proper" federal role in the criminal law. ${ }^{136}$ The lower courts took these declarations of judicial fealty to a limited federal authority as a signal that they could impose an extra-statutory limit on the statute to prevent what they perceived to be an unwarranted extension of federal power. ${ }^{137}$

${ }^{134}$ Sabri, 326 F.3d at 945.

${ }^{135}$ United States v. Suarez, 263 F.3d 468, 489 (6th Cir. 2001), cert. denied, 535 U.S. 991 (2002). The dissent argued, "Given Fischer, it is no longer tenable to hold to the proposition that no connection whatsoever need exist between the federally punished criminal conduct and the federal interest in the programs supported by the funds used to satisfy $\S 666(\mathrm{~b})$." Id . at 486-87 (Boggs, J., dissenting in part).

${ }^{136}$ See Fischer v. United States, 529 U.S. 667, 681 (2000) (A broader interpretation of benefit "would turn almost every act of fraud or bribery into a federal offense, upsetting the proper federal balance."); Salinas v. United States, 522 U.S. 52, 61 (1997) (The application of $\S 666$ to the defendant "did not extend federal power beyond its proper bounds."); $c f$. Cheryl Crumpton Herring, Commentary, 18 U.S.C. $\$$ 666: Is It a Blank Check to Federal Authorities Prosecuting State and Local Corruption?, 52 ALA. L. REV. 1317, 1327 (2001) ("Congress did not consider it necessary to extend the scope of section 666 to the point where it makes a federal crime out of state and local corruption that has no impact on federal funds.").

${ }^{137}$ Frega, 933 F. Supp. at 1540 (" $[\mathrm{I}] \mathrm{t}$ would drastically change the balance of power between federal and state governments by bringing conduct that had previously been entirely in the realm of the states within the federal purview."); United States v. Zwick, 199 F.3d 672, 682-83 (3d Cir. 1999) ("The most literal interpretation— that the statute lacks a federal connection requirement-is troubling from an interpretive standpoint in that it broadens the range of activity criminalized by the statute and alters the existing balance of federal and state powers by encompassing acts already addressed under state law in which the federal government may have little interest."); McCormack, 31 F. Supp. 2d at 186 ("While this broad interpretation of the statute is entirely plausible ... there is no question that it would result in a drastic change in the balance of power between federal and state governments." (citations omitted)). The district court in $\mathrm{McC}$ Cormack asserted 
Interestingly, none of the courts imposing the federal funding connection requirement found $\S 666$ unconstitutional. Instead, they adopted an asapplied approach that purported to rely on the federalism rationale advanced in Lopez and Morrison to declare the prosecution unconstitutional absent proof of the requisite connection to federal funding. The lower courts never acknowledged that the Supreme Court did not use federalism in those cases to rewrite the elements of the offenses at issue, but instead it declared the entire provision unconstitutional as beyond the power of Congress to adopt.

\section{Does the Spending Power Limit the Scope of $\S 666$ ?}

Justice Thomas' dissent in Fischer asserted that "Section 666 was adopted pursuant to Congress's spending power, art. I, $\S 8, \mathrm{cl}$. 1."138 This assertion reiterated the position of a number of federal courts, which view $\S 666$ as grounded in the spending power, under which Congress has the authority to "lay and collect Taxes, Duties, Imposts and Excises, to pay the Debts and provide for the common Defence and general Welfare of the United States . . . ."139 Unlike the Commerce Clause, which authorizes Congress to regulate only "commerce with foreign Nations, and among the several States," "10 the Spending Clause permits Congress to expend funds to promote the "general Welfare of the United States."141 In United States $v$. Butler, ${ }^{142}$ the Court held that "the power of Congress to authorize

that the prosecution was unconstitutional because it "went too far in extending federal power," $i d$. at 185 , but it never explained how it ascertained that the prosecution traversed the line between the federal and state interests. Although the opinion refers to the federalism limitations, it never analyzes how the principle of federalism empowers a court to decide that a case is not a permissible exercise of the national government's power; the opinion only suggests that when a $\S 666$ prosecution exceeds federal authority, the court intuits that the government should not have brought the case. In Frega, the district court's assertion that a broad application of $\S 666$ would "drastically change" the federal-state balance is simply untrue if one considers the application of the Hobbs Act and Mail Fraud statutes to public corruption. Frega, 933 F. Supp. at 1540. Even if one rejects the application of those statutes to corruption by lower-level officials, $\S 666$ in no way displaces the authority of the states to pursue corruption charges.

${ }^{138}$ Fischer, 529 U.S. at 689 n.3.

${ }^{139}$ U.S. CONST. art. I, $\S 8, \mathrm{cl} .1$.

${ }^{140} \mathrm{Id}$. art. I, $\S 8$, cl. 3.

${ }^{141} I d$. art. I, $\S 8$, cl. 1 .

${ }^{142}$ United States v. Butler, 297 U.S. 1 (1936). 
expenditure of public moneys for public purposes is not limited by the direct grants of legislative power found in the Constitution." ${ }^{143}$ While Congress may not regulate in every field, it may expend federal money to achieve a result that it might not otherwise be able to accomplish through direct legislative activity. ${ }^{144}$

Even that broad power, however, is limited because it does not permit Congress to impose any condition it wishes upon those who accept federal funds. South Dakota v. Dole $e^{145}$ is the principal case considering the constitutionality of conditions imposed on states receiving federal funds. The case involved a state's challenge to a condition attached to federal highway funding, which required recipient states to adopt legislation establishing twenty-one as the minimum age to consume alcohol. ${ }^{146}$ The Supreme Court adopted a four-part test for reviewing conditions attached to federal disbursements: (1) "the exercise of the spending power must be in pursuit of "the general welfare"'; (2) the conditions must be unambiguous; (3) conditions must be related "to the federal interest in particular national projects or programs"; and (4) "other constitutional provisions may provide an independent bar to the conditional grant of federal funds." ${ }^{147}$ In upholding the condition at issue, the Court noted that constitutional authority under the Spending Clause is not restricted to those areas in which Congress can regulate directly and that the Tenth Amendment does not "limit the range of conditions legitimately placed on federal grants."148

${ }^{143} I d$. at 66.

${ }^{144}$ See Erwin Chemerinsky, Protecting the Spending Power, 4 CHAP. L. REV. 89,93 (2001) ("[N]o limits on the scope of the spending power can be reasonably inferred from the text of the Constitution."); see also Thomas R. McCoy \& Barry Friedman, Conditional Spending: Federalism 's Trojan Horse, 1988 SUP. CT. REV. 85,102 ("[T]he delegated power to spend money for the general welfare is a power separate from and in addition to all of Congress's specific delegated legislative or regulatory powers.").

${ }^{145}$ South Dakota v. Dole, 483 U.S. 203 (1987).

${ }^{146} \mathrm{Id}$.

${ }^{147} \mathrm{Id}$. at $207-08$.

${ }^{148} I d$. at 210 . The Court also stated, "[O]bjectives not thought to be within Article I's 'enumerated legislative fields' ... may nevertheless be attained through the use of the spending power and the conditional grant of federal funds." Id. at 207 (quoting United States v. Butler, 297 U.S. 1, 65 (1936)). This broad reading of the Spending Clause has been criticized as "unprecedented," and some suggest that it "invited the complete abrogation of any limits on the delegated powers of Congress." McCoy \& Friedman, supra note 144, at 101-02. 
The federal connection requirement imposed by lower courts is not rooted in the language of $\S 666$, which requires only proof that the program or organization received the requisite federal funding in the relevant period, without touching on how the defendant's conduct affected the use of those funds. Instead, the lower courts looked to the constitutional basis for the congressional enactment of the provision as a separate source of judicial authority to limit the reach of the statute. Lower courts assert that $\S 666$ is an exercise of the spending power, and therefore that the statute can apply only to misconduct related to the expenditure of federal funds, in order to be a proper exercise of congressional authority. This is not an analysis of the limits of the Commerce Clause on congressional authority, as the Supreme Court undertook in Lopez and Morrison. Lower courts import a notion of federalism as a separate limit on the spending power. This view empowers courts to create a new element for proving a violation of $\S 666$, preserving what the courts presume to be the requisite distinction between "what is truly national and what is truly local." 49

When evaluating $\S 666$, lower courts seized on the third Dole requirement, that the condition be related to a federal interest, as the basis for limiting the scope of the statute. In McCormack, the district court stated that the germaneness requirement "provides the most plausible attack on $\S$ 666(a)" and that requiring proof of a connection between federal funding and the bribery "is consistent with the limits the Supreme Court has placed on the spending power." 150 The Third Circuit in Zwick held that "absent evidence of any federal interest, [§666] would appear to be an unconstitutional exercise of power under the Spending Clause."151 The Fifth Circuit in Phillips similarly held that the prosecution "advances no federal interest in safeguarding a particular federal program" as required by the Spending Clause if there is no connection between the bribe and federal funding. ${ }^{152}$

${ }^{149}$ United States v. Morrison, 529 U.S. 598, 605-08 (2000) (quoting United States v. Lopez, 514 U.S. 549, 557 (1995)).

${ }^{150}$ United States v. McCormack, 31 F. Supp. 2d 176, 188-89 (D. Mass. 1998).

${ }^{151}$ United States v. Zwick, 199 F.2d 672, 687 (3d Cir. 1999).

152 United States v. Phillips, 219 F.3d 404, 414 (5th Cir. 2000). In United States v. Lipscomb, 299 F.3d 303 (5th Cir. 2002), Judge Weiner argued that $\S 666$ was reasonably related to the federal interest, thereby meeting the third factor of the test, because "Congress could have believed, quite legitimately, that preventing federal funds from passing through state and local legislative bodies whose members are corrupt, and to do so with the deterrent of criminalizing the legislators' corruption, even with respect to purely state or local issues, was necessary and proper to the federal spending power." Id. at 336-37. The United States District 
These courts transformed South Dakota $v$. Dole into a requirement that the government prove an affirmative connection between the criminal act and the federal funding; otherwise the prosecution could be blocked because it was unconstitutional as applied. ${ }^{153}$ This new element of the offense bears no relation to the language of $\S 666$, resting instead on the supposed limits of the spending power as a limited grant of legislative authority that imports the notion of a federal connection between the funds and the criminal prosecution. ${ }^{154}$

It seems self-evident that Congress adopted $\S 666$ pursuant to the spending power because the statutory language ties federal jurisdiction to the transfer of more than $\$ 10,000$ of federal funds in a twelve-month period to the local program or organization in which the corruption occurred. ${ }^{155}$

Court for the District of Connecticut rejected a facial challenge to $\S 666$ because the Second Circuit's nexus requirement saved the statute from an constitutional infirmity. United States v. Ganim, 225 F. Supp. 2d 145 (D. Conn. 2002).

${ }^{153}$ Even Judge Weiner's opinion upholding the constitutionality of a $\S 666$ conviction under the Spending Clause in Lipscomb, considered only the as-applied challenge by an elected legislator in a city that received a significant amount of federal funds. See Lipscomb, 299 F.3d at 303. Reviewing the constitutionality of a prosecution as applied in a particular case to determine whether there is a sufficient federal interest means a court will engage in the same type of scrutiny of the government's evidence as it would under the vague connection requirement recognized by some courts.

154 Interestingly, no court has found a condition attached to spending unconstitutional in any other context because it did not have the necessary relation to a federal interest. See David E. Engdahl, The Spending Power, 44 DuKE L.J. 1, 62 (1994) ("[I]t remains true (so far) that the Supreme Court never actually has held any spending condition unconstitutional for lack of germaneness--whether to the process of spending, or to the purpose of a particular funding program, or to any enumerated end."); Brett D. Proctor, Note, Using the Spending Power to Circumvent City of Boerne v. Flores: Why the Court Should Require Constitutional Consistency in Its Unconstitutional Conditions Analysis, 75 N.Y.U. L. REV. 469, 469 (2000) ("No federal appropriations program has been invalidated by the Supreme Court on federalism-based grounds since 1936.").

${ }^{155}$ A plausible argument can be made that the statute is an exercise of the commerce power and not an enactment solely under the Spending Clause. The statutory requirement of a transfer of $\$ 10,000$ of federal funds to a governmental unit or private agency means that the organization for which the defendant is an agent or employee is likely to have a significant effect on interstate commerce under the third Lopez prong. Moreover, the requirement that the transactions involved in the corruption have a value of at least $\$ 5000$ ensures that there is more than a de minimis effect on interstate commerce. These two elements demonstrate 
Unlike the condition attached to the highway funding in South Dakota $v$. Dole, however, $\$ 666$ is a criminal prohibition that does not operate directly on the states. Courts have not analyzed the scope of congressional power to adopt a criminal law prohibiting bribery under the Spending Clause.

The first two cases to mention the constitutional basis for the statute were two cursory district court decisions-United States v. Bigler ${ }^{156}$ and United States v. Cantor, ${ }^{157}$ issued three days apart-that asserted in dicta that Congress adopted $\S 666$ under its spending power. ${ }^{158}$ Justice Thomas gave his imprimatur to this constitutional analysis in his dissent in Fischer, but his opinion does little more than assert the proposition without any analysis, in much the same way as every other opinion on the subject.

Based only on such meager references to the Spending Clause, courts then assume that $\S 666$ must be a condition attached to the disbursement of federal funds, and therefore subject to the constitutional conditions analysis of South Dakota v. Dole. That assumption, however, is incorrect because the Spending Clause does not, standing alone, confer on Congress the authority to enact laws. Congress may spend money for the "general welfare," but that has never been a source of authority to regulate directly. The Court reviewed the propriety of the conditions attached to the spending in South Dakota v. Dole and, earlier, in Oklahoma v. United States Civil

that both the state or local organization or program and the subject matter of the misconduct have a substantial effect on interstate commerce, and taken together they show that the exercise of authority easily meets the Commerce Clause standard set forth in Lopez. No court has considered whether $\S 666$ may be an exercise of the commerce power. Every judicial opinion that touches the subject assumes, without any real analysis, that the statute is an exercise of the spending power. In addition, the government does not appear to have argued that the statute is valid under the Commerce Clause. See United States v. Sabri, 183 F. Supp. 2d 1145,1154 n.10 (D. Minn. 2002) ("The government has not argued that Congress enacted $\S 666$ pursuant to the exercise of legislative power under the Commerce Clause; therefore, this Court will not consider the issue."), rev'd, 326 F.3d 937 (8th Cir. 2003).

${ }^{156}$ United States v. Bigler, 907 F. Supp. 401 (S.D. Fla. 1995).

${ }^{157}$ United States v. Cantor, 897 F. Supp. 110 (S.D.N.Y. 1995).

${ }^{158}$ In Bigler, a brief opinion rejecting the defendant's motion to dismiss the indictment on the ground that $\$ 666$ was unconstitutional, the Court referred to the Spending Clause in conjunction with the Necessary and Proper Clause, U.S CONST. art. I, $\S 8, \mathrm{cl}$. 18 , as providing a sufficient basis for its enactment. Bigler, 907 F. Supp. at 402 . In Cantor, the district court noted simply that "[t]he parties agree that Congress enacted 18 U.S.C. $\S 666$ pursuant to its spending power." Cantor, 897 F. Supp. at 113. 
Service Commission, on the assumption that Congress did not have the authority to impose the conditions directly on the states; indeed, such direct regulation could raise serious federalism concerns. A condition attached to an offer of federal funds is similar to a contract; it is enforceable against the states unless the financial inducement is "so coercive as to pass the point at which 'pressure turns into compulsion." "159 Congress operates directly on the states under the spending power by attaching the condition to the offer of funds, inducing them to act by offering a benefit that-absent unconstitutional compulsion - they are free to reject. ${ }^{160}$ As the Court noted in South Dakota v. Dole, a condition is not unconstitutional "simply by reason of its success in achieving the congressional objective."161

Congress may incorporate a conditional grant of funds in a law enacted through the same procedures as any other provision adopted under an enumerated power, but that does not give the condition the force of law absent the states' consent by accepting federal funds and adopting their own conforming laws. Professor Engdahl argues, "What makes such conditions obligatory is that essence as contract, wholly apart from the circumstance that they happen to be spelled out in a statute or an agency rule ... they have no force as 'law'; their only force is contractual."162 Unlike the prohibition on commandeering state authority to accomplish a federal goal that the Court articulated in New York v. United States ${ }^{163}$ and Printz v. United States, ${ }^{164}$ the Spending Clause essentially allows Congress

${ }^{159}$ South Dakota v. Dole, 483 U.S. 203, 211 (1987) (quoting Steward Mach. Co. v. Davis, 301 U.S. 548, 590 (1937)).

${ }^{160}$ See Barnes v. Gorman, 536 U.S. 181, 186 (2002) ("Although we have been careful not to imply that all contract-law rules apply to Spending Clause legislation ... we have regularly applied the contract-law analogy in cases defining the scope of conduct for which funding recipients may be held liable for money damages.").

${ }^{161}$ Dole, 483 U.S. at 211.

162 Engdahl, supra note 154, at 71.

${ }^{163}$ New York v. United States, 505 U.S. 144 (1992). The Court held that the Low-Level Radioactive Waste Policy Act came within congressional authority under the Commerce Clause, but that the statute was unconstitutional because "the provision is inconsistent with the federal structure of our Government established by the Constitution." Id. at 177 .

${ }^{164}$ Printz v. United States, 521 U.S. 898 (1997). The Court invalidated the Brady Handgun Violence Protection Act's requirement that state and local officials undertake background checks on prospective handgun purchasers because it violated the anti-comandeering principle of New York $v$. United States. The Court emphasized that the residual state sovereignty protected by federalism meant that 
to enlist the states by offering them a benefit that carries with it a concomitant obligation to fulfill the demands of the federal government. ${ }^{165}$

Section 666 is not a condition imposed on the states to induce them to cooperate with the national government. ${ }^{166}$ Unlike other conditions that Congress attaches to federal funding, ${ }^{167} \S 666$ applies to any program or organization - public or private - that receives federal funds without requiring any further conduct on the part of the recipient. The criminal prohibition exists apart from the payment of the funds, and the jurisdictional requirement that the program receive a certain amount of federal money in a limited period permits the prosecution in federal court but does not operate as a condition on the operation of the program or affect the future receipt of federal funds. If $\S 666$ is a condition, then it is like no other in the law of contracts because it attaches regardless of the recipient's agreement to it, and the term has no effect on the performance of the parties-neither the federal government nor the program or organization receiving the funds-in fulfilling the purported agreement. ${ }^{168}$

Section 666 operates directly on individuals engaged in corruption who were acting on behalf of a program or organization that receives federal

"[t]his separation of the two spheres is one of the Constitution's structural protections of liberty." Id. at 921 .

${ }^{165}$ See Jim C. v. United States, 235 F.3d 1079, 1081-82 (8th Cir. 2000) (en banc) (The requirement that a state comply with a condition attached to federal funding "is comparable to the ordinary quid pro quo that the Supreme Court has repeatedly approved; the State is offered federal funds for some activities, but, in return, it is required to meet certain federal requirements in carrying out those activities.").

${ }^{166}$ See United States v. Sabri, 326 F.3d 937, 945-46 (8th Cir. 2003) ("While traditional Spending Clause legislation is in the 'nature' of a contract, it is not a contract. . . . Instead, 'contract' is used only metaphorically to illuminate and explain certain aspects of the relationship formed between the federal government and the recipient of the federal funds. We find this metaphor useful to our discussion here, and we note that $\S 666$ has none of the hallmarks of a contractual relationship which characterizes typical Spending Clause legislation." (citation omitted)).

167 See, e.g., Rehabilitation Act of $1973 \S 504,29$ U.S.C. $\S 794$ (2003) (prohibiting "any program or activity" receiving federal funds from discriminating against a qualified person with a disability).

${ }^{168}$ See Pennhurst State Sch. \& Hosp. v. Halderman, 451 U.S. 1, 17 (1981) ("The legitimacy of Congress's power to legislate under the spending power thus rests on whether the State voluntarily and knowingly accepts the terms of the 'contract."'). 
funds. ${ }^{169}$ The law does not require that the states, or any of their departments or agencies, do anything as a condition for receiving the funds or suffer any penalty because an agent of the program or organization violated $\S 666$. Instead, the criminal statute reaches individual conduct that involves a misuse of public authority, and it neither makes the proper exercise of state authority a crime under federal law nor permits federal prosecution of the organization because of the conduct of one of its agents. Section 666 prohibits bribery, fraud, and misuse of property - conduct that undermines governmental authority and that would also be subject to prosecution by the states, regardless of the source of funding. ${ }^{170}$

${ }^{169}$ See Sabri, 326 F.3d at 946 ("Unlike typical Spending Clause enactments, § 666 imposes no affirmative obligation on the recipient of federal funds . . . Nor does $\S 666$ proscribe conduct of the recipient of the federal funds." (citations omitted)); see also United States v. Ferrara, 990 F. Supp. 146, 151 (E.D.N.Y. 1998) ("Simply stated, the focus is on the individuals who control the dollars, not the dollars themselves.").

${ }^{170}$ In Oklahoma v. United States Civil Service Commission, 330 U.S. 127 (1947), the Court upheld under the spending power the application to the state of the Hatch Political Activity Act, which prohibits individuals holding governmental appointments from engaging in certain types of political activity. See id. at 143; 5 U.S.C. $\S 1502$ (2000). The statute gives the federal government enforcement powers directly against state programs receiving federal funds whose officials violated the Hatch Act, including withholding funds or an order directing the removal of the official who violated the restrictions on political activity while holding state office. See id. $\S 1506$. Civil Service Commission upheld the predecessor statute, 18 U.S.C. $\S 61$, which is reprinted in full in the case and describes removal from office. See Civil Serv. Comm 'n, 330 U.S. at 129 n.1, 143. The Court held that "[w]hile the United States is not concerned with and has no power to regulate local political activities as such of state officials, it does have power to fix the terms upon which its money allotments to states shall be disbursed." Id. at 143. The Court declined to find a violation of state sovereignty when the federal government sought to force Oklahoma to remove one of its Highway Commission officers, even though the officer's conduct did not violate any state law and there was no allegation of corruption in his political activities. Id. If one accepts that Court's assertion that a federal order to remove a state officer because of political activities not otherwise forbidden by state law-activities certainly protected by the First Amendment - then it is hard to see how $\S 666$ could be a violation of state sovereignty. Unlike the Hatch Act, which seeks to improve public service by requiring appointed government officials to abstain from political activity, $\S 666$ punishes conduct that has long been considered criminal and an abuse of power. Section 666 does not work directly on the states, as the Hatch Act does, and there is no likelihood that a state would permit an official convicted of 
It is misguided to assert that $\S 666$ is a condition attached to federal spending that somehow regulates the states as states. The statute does not affect permissible exercises of state power, but instead misappropriation of resources or corruption in the administration of programs receiving federal funds. ${ }^{171}$ Unlike other types of conditions attached to federal funds, $\S 666$ neither punishes a state or its departments because of a violation, nor precludes future disbursements of federal money to programs affected by corruption convictions. Moreover, the statute reaches both public and

bribery, embezzlement, or fraud to remain in office. The federalism argument would appear to be much stronger against the application of the Hatch Act to the states through the spending power than against a criminal provision, also enacted pursuant to the spending power, which punishes an individual officeholder for clearly improper conduct. See United States v. Gillock, 445 U.S. 360, 371 (1980) ("[R]egulation by Congress under the Commerce Clause of individuals is quite different from legislation which directly regulates the internal functions of states."). Yet, in Civil Service Commission, the Court upheld the federal invasion of a state's prerogative to appoint its own officials because, "even though the action taken by Congress does have effect upon certain activities within the state, it has never been thought that such effect made the federal act invalid." Civil Serv. Comm 'n, 330 U.S. at 143 .

${ }^{171}$ In Pennhurst, 451 U.S. at 17 , the Court stated that "legislation enacted pursuant to the spending power is much in the nature of a contract: in return for federal funds, the States agree to comply with federally imposed conditions." The issue in Pennhurst was whether a "bill of rights" for patients under the Developmentally Disabled Assistance and Bill of Rights Act provided to mentally-impaired patients substantive rights that could be enforced against the states. $I d$. at 2 . The Court held that Congress had not unambiguously imposed the bill of rights as a condition of state acceptance of federal funds, so the Court could not determine whether Congress imposed an obligation on the states "or whether it spoke merely in precatory terms." Id. at 18. The Court's language appears to limit permissible legislation under the Spending Clause to only conditions, but congressional authority under the constitutional grant includes the adoption of legislation related to federal spending that is not in the form of a condition, such as creating a federal regulatory structure or making it a criminal offense to accept a bribe if one is a federal "official." Similarly, in Barnes v. Gorman, 536 U.S. 181 (2002), the Court discussed the constitutionality of an award of punitive damages against a municipality under a statute adopted pursuant to the Spending Clause; the Court emphasized that the contract-law nature of the legislation precluded the imposition of such damages. The Court stated that the contract-law analogy "applies, we think, in determining the scope of damages remedies." See id. at 187. Neither Pennhurst nor Barnes expressly limited the Spending Clause to conditional grants, but instead focused on that issue because it was the source of the private right of action under the applicable statutes. 
private organizations receiving federal funds, as opposed to the conditional federal spending upheld in South Dakota v. Dole or the anti-commandeering rule applied New York and Printz to restrain the assertion of federal authority over the states. In those cases, the statutes at issue operated directly on the states as states, while $\S 666$ is a criminal statute that subjects individual defendants to prosecution.

Unlike conditional spending, $\S 666$ operates after the fact to protect the integrity of governmental power by punishing those who offer and accept bribes, engage in fraudulent activity, or embezzle from their programs or organizations. ${ }^{172}$ Section 666 punishes the miscreant agent, not the faithful government servant. Therefore, it does not usurp state authority to further a federal policy or regulate another sovereign in any way. Section 666 is not a condition attached to federal funding, but rather incorporates the distribution of federal money as the jurisdictional basis for a criminal prosecution to vindicate the national government's interest in protecting against corruption. Therefore, the four requirements of South Dakota $v$. Dole for determining the propriety of federal conditions imposed on the states as part of a grant of funds simply do not provide a basis to read into $\S 666$ a federal connection requirement. ${ }^{173}$

${ }^{172}$ See Fischer v. United States, 529 U.S. 667, 678 (2000) (“This language indicates that Congress viewed many federal assistance programs as providing benefits to participating organizations. Coupled with the broad substantive prohibitions of subsection (a), the language of subsection (b) reveals Congress' expansive, unambiguous intent to ensure the integrity of organizations participating in federal assistance programs."); United States v. Edgar, 304 F.3d 1320, 1326 (11th Cir.), cert. denied, 537 U.S. 1078 (2002) (Fischer's "reference to ensuring integrity, as well as the identification of plural federal assistance programs, suggests a reading of $\S 666$ as serving a Congresional meta-purpose: the creation of an enforcement mechanism sufficient to assure that disbursements meeting the $\$ 666(\mathrm{~b})$ threshold are in fact applied in furtherance of the purposes for which they are dispensed."); United States v. Lipscomb, 299 F.3d 303, 333 (5th Cir. 2002) ("A corrupt state or city official who has real responsibility for, or often participates in, the allocation of federal funds is a 'threat to the integrity' of those funds, even if they are not actually or directly infected by his corruption." (quoting Salinas v. United States, 522 U.S. 52, 61 (1997))).

${ }^{173}$ The test articulated in South Dakota v. Dole, 483 U.S. 203 (1987), helps determine whether a condition is constitutional or not, but it is not a method of statutory interpretation. If a condition attached by Congress violates any of the four parts of Dole, then the condition cannot be enforced. Id. at 207-08. In Pennhurst, 451 U.S. at 17, the Court held that "if Congress intends to impose a condition on the grant of federal moneys, it must do so unambiguously." Id. at 17 . The 


\section{Congressional Authority to Adopt $\S 666$ as an Encompassing Public Corruption Statute}

If $\S 666$ is not a condition appended to a bill that disburses or relates to the distribution of federal funds, the question arises whether Congress has the authority to adopt the statute under the Spending Clause. Although $\S 666$ is not a form of conditional spending, it can still be an exercise of the spending power in conjunction with the authority granted to Congress under the Necessary and Proper Clause. The Constitution provides that Congress has the authority "[t]o make all Laws which shall be necessary and proper for carrying into Execution the foregoing Powers ...."174 While it does not confer on Congress any greater authority than that contained in the enumerated powers, the Necessary and Proper Clause does afford Congress considerable flexibility in adopting statutes that appear to fall beyond the express terms of congressional authority prescribed in the Constitution. ${ }^{175}$

Pennhurst requirement permits courts to scrutinize whether in fact Congress sought to impose a condition on a state receiving funds. If it did impose a condition then, absent an improper exercise authority under South Dakota v. Dole, the condition will be upheld because Congress is not limited under the Spending Clause in how it may choose to spend federal funds to advance federal policies. Courts that rely on the germaneness requirement to impose a limit on the scope of $\S 666$ misuse the Dole test by viewing it as a measure that permits courts to reformulate a congressional enactment to ensure a relation to a federal interest in the particular prosecution. The test for conditions does not apply to a criminal statute that is not a condition attached to federal spending. Similarly, the clear statement requirement of Pennhurst is inapplicable because Congress need not speak any more clearly than it must in other criminal statutes regarding the scope of $\S 666$; the plain language of the statute controls its application, as the Court held in Salinas. See Salinas, 522 U.S. at 57-58. But see Lipscomb, 299 F.3d at 321 ("Therefore, although we may debate whether the $\S 666$ peg fits the conditional-grant hole, I shall test it under the four prongs of Dole.").

${ }^{174}$ U.S. CONST. art. I, § 8, cl. 18.

${ }^{175}$ See United States v. Sabri, 326 F.3d 937, 951 (8th Cir. 2003) ("[Section] 666 was designed to protect the integrity of the vast sums of federal monies disbursed through federal programs."); Edgar, 304 F.3d at 1325 ("As a means of ensuring the efficacy of federal appropriations to comprehensive federal assistance programs, the anti-corruption enforcement mechanism strikes us as bearing a sufficient relationship to Congress's spending power to dispel any doubt as to its constitutionality."); Lipscomb, 299 F.3d at 324 ("Prosecuting Lipscomb under $\S 666$ is therefore constitutional if $\S 666$ is 'necessary and proper' to Congress's spending 
Chief Justice Marshall's venerable opinion in $M^{\prime} C u l l o c h v$. Maryland ${ }^{176}$ set forth the broad reading of the Necessary and Proper Clause: "Let the end be legitimate, let it be within the scope of the constitution, and all means which are appropriate, which are plainly adapted to that end, which are not prohibited, but consist with the letter and spirit of the constitution, are constitutional." 177 Marshall viewed federal criminal statutes as the prototypical example of the type of legislation that, while outside the express powers granted to Congress, was a proper exercise of the implied power conferred by the Necessary and Proper Clause. He wrote, "The good sense of the public has pronounced, without hesitation, that the power of punishment appertains to sovereignty, and may

power."). Professor Engdahl asserts that $\S 666$ cannot be based on the spending power because "Congress has no more power to punish theft from the beneficiaries of its largesse than it has to punish theft from anyone else . . . Money cannot infect the recipient with the germ of generalized federal governing control, or an infectious virus capable of spreading that disease to anyone who touches the recipient or its property." Engdahl, supra note 154, at 92. Picaresque language aside, the conclusion misconstrues $\S 666$ and congressional authority to adopt criminal provisions. Section 666 punishes certain forms of corruption, and the federal funding provides the basis for federal jurisdiction but does not make it a crime simply to steal money. Moreover, Congress uses its authority under the Commerce Clause to punish conduct related to theft, such as the interstate transportation of stolen property. See 18 U.S.C. $\S 2314$ (2000) ("Whoever transports, transmits, or transfers in interstate or foreign commerce any goods, wares, merchandise, securities or money, of the value of $\$ 5,000$ or more, knowing the same to have been stolen, converted or taken by fraud ... [s] hall be fined under this title or imprisoned ...."). The classic state law offense of rustling cattle-a staple of most Westerns — can be a federal offense. See 18 U.S.C. $\S 2316$ (2000) ("Whoever transports in interstate or foreign commerce any livestock, knowing the same to have been stolen, shall be fined under this title or imprisoned. ..."). The federal funds are not a "germ," but instead an acceptable limitation on federal criminal jurisdiction to a limited range of cases that vindicate the national government's interest in preventing and punishing corruption at any level of government. Conditions imposed on the states under statutes adopted pursuant to the spending power are laws under the Supremacy Clause: the key is whether Congress validly adopted the spending provision, and not what effect the funds have on a recipient. See Westside Mothers v. Haveman, 289 F.3d 852, 860 (6th Cir. 2002), cert.denied, 537 U.S. 1045 ("The well-established principle that acts passed under Congress's spending power are supreme law has not been abandoned in recent [Supreme Court] decisions.").

${ }^{176}$ M'Culloch v. Maryland, 17 U.S. (4 Wheat.) 316 (1819).

${ }^{177} \mathrm{Id}$. at 421. 
be exercised, whenever the sovereign has a right to act, as incidental to his constitutional powers." 178

Subsequent nineteenth-century decisions followed the analysis of $M^{\prime}$ Culloch v. Maryland in upholding the authority of Congress to enact criminal laws to punish violations related to exercises of an enumerated power. In United States $v$. Fox, ${ }^{179}$ the Court upheld a federal criminal statute punishing the obtaining of goods under false pretenses within three months of filing a bankruptcy petition, stating that, taken together, the Bankruptcy Clause and the Necessary and Proper Clause yielded "no doubt of the competency of Congress to provide, by suitable penalties, for the enforcement of all legislation necessary or proper to the execution of powers with which it is intrusted." ${ }^{\prime 180}$ In United States $v$. Hall, ${ }^{181}$ the Court upheld a statute making it a crime for the guardian of a child, aged sixteen or under, to embezzle or fraudulently convert pension funds paid by the United States to the child. Rejecting the argument that the statute was beyond congressional power because the crime was an offense only under state law, the Court relied on the Necessary and Proper Clause to hold that "[b]ecause the fund proceeds from the United States, and inasmuch as the donation is a voluntary gift, the Congress may pass laws for its protection, certainly until it passes into the hands of the beneficiary . . .."182

Section 666 is directly related to the Spending Clause, because it depends on the expenditure of federal money as the trigger for the requisite federal constitutional interest in criminal enforcement. Congressional authority under the spending power is not only limited to attaching conditions to a disbursement of funds, such as the requirement upheld in Dole, but also includes the authority to protect the federal interest in preventing and prosecuting corruption when federal funds are present. ${ }^{183}$

${ }^{178}$ Id at 418 . Chief Justice Marshall used the example of the postal power and the crime of theft of mail, noting that " $[\mathrm{i}] \mathrm{t}$ may be said, with some plausibility, that the right to carry the mail, and to punish those who rob it, is not indispensably necessary to the establishment of a post-office and post-road." Id. at 417 . He rejected the "baneful influence of this narrow construction on all the operations of the government, and the absolute impracticability of maintaining it ...." Id. at 41718.

${ }^{179}$ United States v. Fox, 95 U.S. 670 (1877).

${ }^{180} \mathrm{Id}$. at 672

${ }^{181}$ United States v. Hall, 98 U.S. 343 (1878).

${ }^{182} I$ d. at 357-58.

${ }^{183}$ See United States v. Sabri, 326 F.3d 937, 951 (8th Cir. 2003) (“Congress has made a determination that the most effective way to protect the integrity of federal funds is to police the integrity of the agencies administering those funds."); United States v. Edgar, 304 F.3d 1320, 1327 (11th Cir. 2002) ("It is reasonable for 
The Anti-Corruption Legacy of the Constitution becomes relevant because the interest of the national government includes ensuring that corruption does not affect the exercise of public authority in state and local governments. This strong federal interest permits Congress to enact $\S 666$ as an appropriate means to the constitutional end of spending federal money. ${ }^{184}$

Unlike a condition designed to co-opt the states into advancing a federal policy they might otherwise not pursue, $\S 666$ does not achieve an objective that could not be obtained under other enumerated powers. Congress clearly could make bribery and embezzlement involving state and local officials a federal crime under the Commerce Clause, as it did in the Hobbs Act. ${ }^{185}$ Corruption is largely an economic offense; it is not a crime of violence or one with only an attenuated commercial effect. Misuse of governmental authority enriches both officeholders and those offering bribes because it is likely to result in a misallocation of governmental resources. Rather than act under its commerce power, however, Congress chose a more limited means to address bribery involving lower-level officials that is far short of what it could have achieved. ${ }^{186}$

Those arguing that $\S 666$ implicitly requires a connection between the federal funds and the prosecuted corruption contend that the statute

Congress to conclude that any corruption of such recipient organizations, regardless of whether the corruption involves the misappropriation of specifically federal funds, endangers the comprehensive programs in which the organizations participate, and thus the effective exercise of the Congressional spending power as well.").

${ }^{184}$ See Sabri, 326 F.3d at 949 ("Applying the $M$ 'Culloch framework, we conclude that $\S 666$ is a law necessary and proper to the execution of Congress's spending power."). But see Engdahl, supra note 154, at 93 ("Hamilton's spending power view does not posit Congress as competent to do anything toward extraneous (i.e., nonenumerated) ends, except spend.").

${ }^{185}$ See United States v. Gillock, 445 U.S. 360, 371 (1980) ("[R]egulation by Congress under the Commerce Clause of individuals is quite different from legislation which directly regulates the internal functions of states.") (citation omitted); $c f$. infra note 208 (discussing how $\S 666$ could be an exercise of the commerce power).

${ }^{186}$ In addition to the statutory elements that the government must prove for federal jurisdiction, Congress explicitly excluded "bona fide salary, wages, fees, or other compensation paid, or expenses paid or reimbursed, in the usual course of business" from providing the basis for prosecution under the statute. See 18 U.S.C. $\S 666$ (c) (2000). These transactions certainly affect commerce, and could provide a constitutionally permissible avenue for federal jurisdiction, but Congress limited the scope of the provision to the types of corrupt transactions that affect the integrity of governmental programs and policies on a larger scale. 
represents an unprecedented extension of federal authority into the domain of the state and local government, reaching crimes in which there is no federal interest. If one accepts that certain crimes should not be subject to federal prosecution, then an external limit located in the Constitution can be imposed. This analysis, however, ignores the fact that Congress imposed jurisdictional limits on cases brought under $\S 666$, and these limits belie the assertion that the statute exceeds the proper scope of federal interests.

Congress adopted three separate jurisdictional requirements in $\S 666$, which operate to limit federal involvement in prosecuting state and local corruption. First, the government must demonstrate that the program or organization received $\$ 10,000$ in federal funds within a twelve-month period. ${ }^{187}$ Courts taking a critical view of $\S 666$ assert that this element is almost trivial, because every state and local government of any size receives at least that amount. That Congress chose a low threshold to trigger federal jurisdiction does not mean the element is meaningless, ${ }^{188}$ and the important federal interest in combating corruption supports Congress' decision to reach a broad array of improprieties by governmental officials. The $\$ 10,000$ requirement represents a permissible judgment by Congress that corruption in all but the smallest governmental units and local programs - where corruption is unlikely to occur due to the limited funding and small scale of the operation-should be subject to federal prosecution. ${ }^{189}$

${ }^{187} 18$ U.S.C. $\S 666(\mathrm{~b})$.

${ }^{188}$ See United States v. Jackson, 313 F.3d 231, 238 (5th Cir. 2002) (reversing $\S 666$ conviction because "[o]ur extensive review of the record reveals a dearth of evidence to support the essential element that the City received more than $\$ 10,000$ per year in federal funds.").

${ }^{189}$ In Sabri, 326 F.3d at 951, the court held:

The maladministration of funds in one part of an agency can affect the allocation of funds, whether federal or local in origin, throughout an entire agency. Thus, to suggest that corruption involving a discrete department or section of an agency that does not itself receive federal funds or administer a federal program can have no effect on the integrity or efficacy of a federal program is to ignore the fact that money is fungible and that federal funds are often comingled with funds from other sources. Section 666 addresses this problem by policing the integrity of the entire organization that receives federal benefits. In sustaining the constitutionality of $\S 666$ under the Necessary and Proper Clause, the Eleventh Circuit recently has come to the Id. same conclusion. 
Second, in order to fall under $\$ 666$, transactions must involve property "valued at $\$ 5,000$ or more," 190 or bribes must be "in connection with any business, transaction, or series of transactions . . . involving anything of value of $\$ 5,000$ or more . . ."191 Unlike the Commerce Clause elements found in a number of federal statutes, which require only that the misconduct "affect interstate commerce" or that there be actual movement across state lines in relation to the offense, $\S 666$ imposes a non-trivial dollar threshold for jurisdiction that limits federal prosecution of corruption involving an identifiable economic harm or relation to valuable commercial transactions. ${ }^{192}$

${ }^{190} 18$ U.S.C. $\S 666(\mathrm{a})(1)(\mathrm{A})(\mathrm{i})$.

${ }^{191}$ Id. $\S 666(\mathrm{a})(1)(\mathrm{B})$.

192 See United States v. Ferrara, 990 F. Supp. 146, 151 (E.D.N.Y. 1998) ("[T] he $\$ 5,000$ value requirement is present to limit federal jurisdiction to significant, i.e., important transactions, again viewed from the protected organization's perspective."); United States v. Apple, 927 F. Supp. 1119, 1125 (N.D. Ind. 1996) ("The $\$ 5,000$ value requirement is what keeps the statute from making a federal violator out of the motorist who bribes a federally subsidized police officer with $\$ 20$ to avoid a $\$ 50$ traffic ticket. As such, the $\$ 5,000$ requirement is the finishing touch on the federal funds 'hook' that starts with the other requirements that the bribed agency received substantial federal funds and that the bribe be connected to the agency business.").

Professor Brown minimizes the value limitations of $\S 666$, arguing that "[i]t is true that the five thousand dollar valuation requirement would function as something of a limit, although a large range of transactions and jurisdictions would be included," and that the federal funds element "is not much of" a limitation either. Brown, Stealth Statute, supra note 104, at 274-75. The criticism is misguided because the breadth of the statute alone is irrelevant to the question of whether it is an impermissible use of federal authority. The important point is that Congress voluntarily limited the scope of $\S 666$ to reach corruption in most governmental units that involves a clear economic harm. Professor Brown argues that the statute is much broader than it appears, and asserts that the provision may be appealing because prosecutors can use it "without the need to satisfy such annoying jurisdictional predicates as use of the mails, effect on commerce, or interstate travel." $I d$. at 274 . While $\S 666$ 's jurisdictional elements may be easy to prove in many cases, they impose at least as great a burden on the government as does the comparable version of the Hobbs Act, which requires only an effect on interstate commerce; or the mail fraud statute, which requires only a mailing incidental to an essential part of the scheme to defraud. See Schmuck v. United States, 489 U.S. 705, 710-11 (1989) ("To be part of the execution of the fraud, however, the use of the mails need not be an essential element of the scheme. . . It is sufficient for the mailing to be "incident to an essential part of the scheme, ... or 'a step in [the] plot." " (quoting Badders v. United States, 240 U.S. 391, 394 
Third, the statute reaches only agents of organizations or programs receiving the federal funds, not simply any person exercising state authority. Section 666 does not permit prosecution of every instance of bribery or commercial corruption, but instead only corruption in government and those private programs receiving the requisite federal benefits. ${ }^{193}$ The agency element shows that Congress exercised its authority only in a limited sphere that implements the Anti-Corruption Legacy of the Constitution.

Courts seeking to limit the application of $\S 666$ sometimes point to its sparse legislative history, in which Congress asserted its purpose for adopting the statute was to permit prosecutions that might have been precluded had the Supreme Court taken a narrow approach in interpreting the scope of $\S 201$ in Dixson. ${ }^{194}$ Under this view, $\S 666$ is only a limited measure reaching at most a slightly broader class of defendants than $\S 201$. The claim that $\S 666$ was a gap-filling provision-and rendered largely unnecessary after the expansive interpretation of $\S 201$ in Dixson-permits courts to interpret otherwise broad statutory language to avoid finding that the statute significantly expanded the federal authority to prosecute corruption. ${ }^{195}$

(1916)). The ease with which the government can obtain proof of a jurisdictional element is irrelevant to the constitutional question of whether Congress can reach the conduct under its enumerated powers. If the authority exists, then the policy choice to make a successful prosecution more or less difficult is one left to Congress and not subject to judicial review.

${ }^{193}$ See, e.g., United States v. Copeland, 143 F.3d 1439, 1441 (11 th Cir. 1998) (overturning conviction under $\S 666$ for bribery involving Lockheed Corporation, which was acting as a prime contractor for the Defense Department, because "organizations engaged in purely commercial transactions with the federal government are not subject to $\S 666$."); United States v. Pretty, 98 F.3d 1213, 1219 (10th Cir. 1996) ("If [defendant] was an agent of the state, rather than only of the Treasurer, then $\S 666$ applies to her even if the Treasurer did not benefit from the federal funds, because the state itself received and benefited from more than $\$ 10,000$ in federal funds.").

${ }^{194}$ See supra note 86 and accompanying text.

${ }^{195}$ In United States v. Lipscomb, 299 F.3d 303 (5th Cir. 2002), Judge Weiner argued that early drafts of the provision that eventually became $\S 666$ were much narrower and would have required proof of a nexus between the federal funds and the corruption. Id. at 328 . While the ultimate congressional purpose is not clear in the legislative history, Judge Weiner pointed out, "[f]or all we know, the [Senate Judiciary] Committee might well have sought to exercise federal criminal jurisdiction up to its constitutional limit, leaving the issue to the courts to decide." Id. 
The introduction to the Senate Report on the provision states that the new section will "augment the ability of the United States to vindicate significant acts of theft, fraud and bribery involving federal monies. . .".196 The reference to "federal monies" has been viewed as a basis for recognizing a requirement that permissible prosecutions under $\S 666$ must embody some nexus - however that term might be defined - for federal jurisdiction. The Senate Report's brief description of the provision, which is the entirety of the legislative history, notes only that the law redressed a "serious gap" by "assuring the integrity of such program funds" and would reach corruption that might not be covered by $\S 201 .{ }^{197}$ An earlier draft of the provision would have required proof of a nexus, but Congress did not enact that bill. ${ }^{198}$ The legislative history for $\$ 666$ does not refer to any additional requirement that prosecutors must demonstrate the federal interest beyond the elements set forth in the statute.

The broad language of $\S 666$ permits courts to rely on federalism as a separate limit on the Spending Clause, rewriting the statute to rein in federal prosecutors and to prevent prosecution of crimes a judge may label "truly local." 199 Employing federalism as the basis for imposing an external

${ }^{196}$ S. REP. No. $98-225$, at 369 (1983), reprinted in 1984 U.S.C.C.A.N. 3182 , 3510.

${ }^{197} I d$. The Report specifically mentioned the circuit court decisions in Del Toro, Hinton, and Mosley as cases that could be prosecuted under the new provision. Id. at 3511 .

${ }^{198}$ The 1981 bill, proposing federal criminal code revisions concerning theft and commercial bribery, premised federal jurisdiction over agents of state and local governments or their fiduciaries who are "charged . . with administering monies or property derived from a federal program ...." United States v. Coyne, 4 F.3d 100 (2d Cir. 1993) (citing S. 1630, 97th Cong., § 1751(c)(1)). The Senate Report on $\S 666$ stated that the provision "is derived from S. 1630, the Criminal Code Reform Act of 1981 approved by the Committee in the 97th Congress." S. REP. NO. 98-225, at 369 (1983), reprinted in 1984 U.S.C.C.A.N. 3182, 3510. In Coyne, 4 F.3d at 100, the Second Circuit noted that the 98th Congress' decision not to adopt this section suggested that it did not wish for prosecutions under 18 U.S.C. $\S 666$ to be limited to "property or conduct related to a program directly funded by the federal government." Id. at 110.

199 The Court in Dixson contrasted its interpretation of $\S 201$ with a broader approach by noting that "we do not mean to suggest that the mere presence of some federal assistance brings a local organization and its employees within the jurisdiction of the federal bribery statute or even that all employees of local organizations responsible for administering federal grant programs are public officials within the meaning of section 201(a)." United States v. Dixson, 465 U.S. 482,499 (1984). Section 666 is exactly the type of statute described in Dixson, and 
constraint on the application of $\S 666$ contradicts the approach Congress took to protect not just federal funds but also the integrity of state and local governments. ${ }^{200}$ The federal interest in preventing and punishing corruption supports the broad reading of $\S 666$ in Salinas and Fischer as a powerful anti-corruption statute that reaches misconduct beyond what other federal criminal statutes had covered. ${ }^{201}$

Judicial discomfort with federal involvement in prosecuting state and local officials does not provide a basis for courts to restrict the authority of Congress to redress corruption in a broad array of programs, both those administered by state and local governments and those operated through private organizations that receive federal funds. Congress expanded the scope of federal authority in $\S 666$ to make it clear that federal prosecutors can target corruption in most governmental units and private programs receiving substantial federal support. Using federalism's purported limiting effect on the Spending Clause as the basis for imposing a vague external limit on $\S 666$ to protect conduct that a court perceives as "truly local" contradicts congressional intent by impermissibly undermining a legitimate exercise of federal authority.

\section{Extortion Under Color of Official Right: The Hobbs Act}

Congress enacted the Hobbs Act in 1946 as a successor to the AntiRacketeering Act of $1934,{ }^{202}$ which the Supreme Court interpreted narrowly

Congress' intent in adopting the new provision was to ensure that there was broad federal authority to prosecute state and local corruption.

${ }^{200}$ See United States v. Sabri, 326 F.3d 937, 952 (8th Cir. 2003) ("The $\$ 10,000$ threshold requirement and the $\$ 5000$ transactional requirement create a sufficient nexus between the offense conduct and federal funds to ensure that federal power will not be extended to the prosecution of merely local matters that may not jeopardize in any significant manner the integrity of federal programs."); United States v. Edgar, 304 F.3d 1320, 1327 (11th Cir. 2002) ("Indeed, for Congress to exercise its spending power effectively, it must be assured that the instrumentalities through which the federal government pursues comprehensive aims can be trusted to apply appropriated funds toward their intended objectives.").

201 See United States v. Apple, 927 F. Supp. 1119, 1125 (N.D. Ind. 1996) ("Congress did not write in the bribery provision, 'anything belonging to the agency of value of $\$ 5,000$ or more,' although it could have. Rather, Congress left that particular provision less specific. [This] Court takes that lack of specificity not to be an inadvertent slip-up in otherwise precise drafting, but instead, deliberately broad drafting.").

${ }^{202}$ Anti-Racketeering Act of 1934, ch. 569, 48 Stat. 979 (1934) (codified as amended at 18 U.S.C. $\S 1951$ (2003)). 
in United States v. Local 807, International Brotherhood of Teamsters ${ }^{203}$ to exclude racketeering activity related to labor disputes. The Hobbs Act reaches robbery and extortion that affect commerce, and it defines extortion as "the obtaining of property from another, with his consent, induced by wrongful use of actual or threatened force, violence, or fear, or under color of official right." 204 The statute is an exercise of the commerce power, and the Court stated that the provision "manifest[s] a purpose to use all the constitutional power Congress has to punish interference with interstate commerce by extortion, robbery or physical violence."205

${ }^{203}$ United States v. Local 807, Int'l Bhd. of Teamsters, 315 U.S. 521 (1942). ${ }^{204} 18$ U.S.C. $\S 1951$ (b)(2) (2000) (emphasis added). The Hobbs Act provides: (a) Whoever in any way or degree obstructs, delays, or affects commerce or the movement of any article or commodity in commerce, by robbery or extortion or attempts or conspires so to do, or commits or threatens physical violence to any person or property in furtherance of a plan or purpose to do anything in violation of this section shall be fined under this title or imprisoned not more than twenty years, or both.

(b) As used in this section-

(1) The term "robbery" means the unlawful taking or obtaining of personal property from the person or in the presence of another, against his will, by means of actual or threatened force, or violence, or fear of injury, immediate or future, to his person or property, or property in his custody or possession, or the person or property of a relative or member of his family or of anyone in his company at the time of the taking or obtaining.

(2) The term "extortion" means the obtaining of property from another, with his consent, induced by wrongful use of actual or threatened force, violence, or fear, or under color of official right.

(3) The term "commerce" means commerce within the District of Columbia, or any Territory or Possession of the United States; all commerce between any point in a State, Territory, Possession, or the District of Columbia and any point outside thereof; all commerce between points within the same State through any place outside such State; and all other commerce over which the United States has jurisdiction.

Id. $\S 1951$.

${ }^{205}$ Stirone v. United States, 361 U.S. 212, 215 (1960). The Hobbs Act applies to every robbery and extortion that "in any way or degree obstructs, delays, or affects commerce or the movement of any article or commodity in commerce...." 18 U.S.C. $\S 1951$ (a). Courts have found that the Hobbs Act requires only that the government prove the misconduct had a "minimal impact" on commerce. United States v. Castleberry, 116 F.3d 1384, 1388 (11 th Cir. 1997). 
The Hobbs Act does not specifically address corruption, but in the early 1970s federal prosecutors sought to charge under the Act state and local officials who accepted bribes and kickbacks. The prosecutors argued that the acceptance of an unauthorized benefit by a local official constituted extortion under color of official right. ${ }^{206}$ Lower courts readily agreed to the government's interpretation of extortion as the equivalent of accepting bribes, a position that was ultimately endorsed by the Supreme Court. ${ }^{207}$ The Hobbs Act became one of the primary weapons for prosecuting bribery that fell outside $\S 201$ because of that statute's limitation to federal officials and those exercising federal authority. ${ }^{208}$

Even before the Court's decisions in Lopez and Morrison, Justice Thomas raised federalism concerns about the application of the Hobbs Act to local officials not directly responsible to the federal government. In Evans v. United States, ${ }^{209}$ the Court, in upholding the Hobbs Act conviction of a local elected official, rejected the argument that extortion requires the official to have initiated or induced the corrupt payment rather than being a passive recipient of a bribe. ${ }^{210}$ Justice Thomas dissented, arguing that

${ }^{206}$ See McCormick v. United States, 500 U.S. 257, 266 n.5 (1991) ("Until the early 1970's, extortion prosecutions under the Hobbs Act rested on allegations that the consent of the transferor of property had been 'induced by wrongful use of actual or threatened force, violence, or fear'; public officials had not been prosecuted under the 'color of official right' phrase standing alone. Beginning with the conviction involved in United States v. Kenny, 462 F.2d 1205 (3rd Cir. 1972), however, the federal courts accepted the Government's submission that because of the disjunctive language of $\S 1951$ (b)(2), allegations of force, violence, or fear were not necessary. Only proof of the obtaining of property under claims of official right was necessary.").

${ }^{207}$ See Evans v. United States, 504 U.S. 255, 260 (1992) ("Extortion by the pubic official was the rough equivalent of what we would now describe as "taking a bribe." ").

208 See Peter D. Hardy, Note, The Emerging Role of the Quid Pro Quo Requirement in Public Corruption Prosecutions under the Hobbs Act, $28 \mathrm{U}$. MICH. J.L. REFORM 409, 411 (1995) ("This interpretation of the Hobbs Act, which obviated the need to demonstrate coercion on the part of a public official, paved the way for the Hobbs Act to blossom into an especially effective antibribery statute.").

${ }^{209}$ Evans, 504 U.S. at 255.

${ }^{210}$ Id. at 265-66 ("First, we think the word 'induced' is a part of the definition of the offense by the private individual, but not the offense by the public official.... Second, even if the statute were parsed so that the word 'induced' applied to the public officeholder, we do not believe the word 'induced' necessarily indicates that the transaction must be initiated by the recipient of the bribe."). The defendant, a county commissioner in Georgia, was first approached by an under- 
"[o]ver the past 20 years, the Hobbs Act has served as the engine for a stunning expansion of federal criminal jurisdiction into a field traditionally policed by state and local laws - acts of public corruption by state and local officials." ${ }^{211}$ Relying on statements in United States v. Bass ${ }^{212}$ and Gregory v. Ashcroft ${ }^{213}$ that expressed concern with the effect of broad interpretations of federal law that would intrude on areas traditionally subject to state regulation, Justice Thomas asserted that the application of the Hobbs Act to local officials amounted to a regulation of state governments that "mocks" earlier decisions limiting the power of Congress to regulate the states. ${ }^{214}$

cover FBI agent offering a bribe for assistance on a zoning matter that was to come before the county commission for approval. Id. at 257 .

${ }^{211}$ Id. at 290 (Thomas, J., dissenting).

${ }^{212}$ United States v. Bass, 404 U.S. 336 (1971).

${ }^{213}$ Gregory v. Ashcroft, 501 U.S. 452 (1991).

${ }^{214}$ Evans, 504 U.S. at 294 (Thomas, J., dissenting). In Bass, the Court interpreted the elements of a gun possession statute and noted "a second principle supporting today's result: unless Congress conveys its purpose clearly, it will not be deemed to have significantly changed the federal-state balance." Bass, 404 U.S. at 349. In Gregory v. Ashcroft, the Court cited Bass for the proposition that an interpretation of legislation that significantly altered the federal-state balance required a clear expression of congressional intent. Gregory, 501 U.S. at 461. In both cases, the Court invoked the federal-state balance in support of its narrow interpretation of the statute at issue. The Court did not, however, find that Congress lacked the authority to legislate in the area if it chose to do so, but instead only that Congress must make that intention clearer. The cases do not appear to construct an impenetrable barrier to federal regulation, as Justice Thomas' dissent implies.

Justice Thomas also questioned the decision by the federal prosecutor to pursue the case, stating that "[o]ur criminal justice system runs on the premise that prosecutors will respect, and courts will enforce, the boundaries on criminal conduct set by the legislature. Where, as here, those boundaries are breached, it becomes impossible to tell where prosecutorial discretion ends and prosecutorial abuse, or even discrimination, begins." Evans, 504 U.S. at 296. Justice Thomas was troubled by the use of undercover agents offering bribes as a means to investigate local elected officials; this method of apprehension had the appearance of federal officials inducing local representatives to engage in criminal conduct. He did not argue that the defendant was entrapped. Instead, he asserted that the conduct did not violate the statute because the Court's opinion impermissibly created a new offense through its "expansive interpretation of the crime. But that interpretation has no basis in the statute that Congress passed in 1946." Id. The propriety of the government's investigative techniques does not have any relevance to the issue of the constitutionality of a statute. 
Justice Thomas misconstrued the application of federalism to criminal laws because he mistakenly viewed the Hobbs Act as regulating the conduct of the states and their officials in matters of official policy, similar to the legislation at issue in Gregory v. Ashcroft. The Hobbs Act reaches the misuse of governmental authority; thus, it is not a regulation of the states or a limit on their power. That the defendants may be state and local officials, also subject to prosecution by the states for their conduct, does not remove them from the power of the federal government. In United States v. Gillock, ${ }^{215}$ the Court rejected the argument that federalism required the federal courts to recognize a privilege similar to the Speech or Debate Clause that would prohibit the use of state legislative acts and statements as evidence of a Hobbs Act violation by a state senator. ${ }^{216}$ The Court noted that criminal prosecutions act only on the individual official and not the state, so that "recognition of an evidentiary privilege for state legislators for their legislative acts would impair the legitimate interest of the Federal Government in enforcing its criminal statutes with only speculative benefit to the state legislative process." 217 The Court concluded, "In the absence of a constitutional limitation on the power of Congress to make state officials, like all other persons, subject to federal criminal sanctions, we discern no basis in these circumstances for a judicially created limitation that handicaps proof of the relevant facts." 218

Gillock recognized that the federal authority to prosecute corruption by state and local officials may have some tangential effect on the operation of the states, but the national government has a powerful interest in enforcing its corruption laws even when there is some interference with the exercise of state power. Federalism does not operate as a separate limit on the prosecution of corruption, nor does it mean that crimes already subject to state prosecution presumptively should be removed from the authority of the federal government.

${ }^{215}$ United States v. Gillock, 445 U.S. 360 (1980).

${ }^{216}$ The Speech or Debate Clause, U.S. CONST. art. I, § 6, cl. 1, prohibits the government from, inter alia, introducing any of the legislative acts of Senators and Representatives in a prosecution of that official. See United States v. Helstoski, 442 U.S. 477, 489 (1979) ("The Clause protects 'against inquiry into acts that occur in the regular course of the legislative process and into the motivation for those acts.' " (quoting United States v. Brewster, 408 U.S. 501, 525 (1972))). The Tennessee Constitution also provides a Speech or Debate protection in state prosecutions. TENN. CONST. art. II, $\S 13$.

${ }^{217}$ Gillock, 445 U.S. at 373.

${ }^{218} I d$. at 374. 
The broad commerce element in the Hobbs Act also has caused some lower court judges to assail the application of the Hobbs Act to robberies traditionally prosecuted by local authorities. In United States $v$. McFarland ${ }^{219}$ and United States v. Hickman ${ }^{220}$ a substantial block of Fifth Circuit judges twice questioned the statute's application to a series of small-scale robberies. These judges dissented from the affirmance of the convictions by an equally divided en banc court in both cases. In McFarland, the dissenting judges asserted,

There is no sufficient rational basis to aggregate the effects on interstate commerce of any of the four individual prototypically local crimes of violence here prosecuted with the effects on interstate commerce of all the undifferentiated mass of robberies covered by the Hobbs Act's general proscription of any and all robberies that "in any way or degree ... affect ... commerce.,221

In Hickman, the dissenting judges argued that these "Hobbs Act prosecutions exceeded Congress's authority,"222 because permitting prosecutors to establish the commerce element by aggregating the effect of the robberies meant that "[ $t]$ aking a child's lemonade is as potentially covered as any other robbery, at least as long as we are free to aggregate all robberies."223

Neither McFarland nor Hickman was a public corruption case, and the dissenting judges' position relied on the need to limit federal authority over crimes of violence that did not involve commercial activity. ${ }^{224}$ If the Hobbs

${ }^{219}$ United States v. McFarland, 311 F.3d 376 (5th Cir. 2002) (en banc), cert. denied, 155 L. Ed. 515 (2003).

${ }^{220}$ United States v. Hickman, 179 F.3d 230, 231 (5th Cir. 1999)(Higginbotham, J., dissenting from affirmance of conviction by an equally divided en banc court).

${ }^{221}$ McFarland, 311 F.3d at 409 (Garwood, J., dissenting).

${ }^{222}$ Hickman, 179 F.3d at 231 (Higginbotham, J., dissenting).

${ }^{223}$ Id.; see also United States v. Marrero, 299 F.3d 653, 655 (7th Cir. 2002), cert. denied, 537 U.S. 1145 (2003) (upholding Hobbs Act conviction for robbery, but noting that " $[w]$ e are troubled, however, by the inability of the government's lawyer either in his brief or at argument to suggest a limiting principle in Hobbs Act prosecutions, despite the Supreme Court's evident concern not to allow the concept of 'commerce' (interstate or foreign) to expand to the point at which every transaction in the American economy would be within Congress's reach").

${ }^{224}$ See McFarland, 311 F.3d at 396 (Garwood, J., dissenting) ("Robbery is the 'activity' regulated by the Hobbs Act, and we conclude that for these purposes robbery cannot be considered a commercial activity."). The dissenting judges analyzed only a violation of the Hobbs Act through conduct constituting the 
Act does not apply to that type of crime because of federalism limitations on the Commerce Clause power of Congress to regulate such activity, then there could be a sharp distinction between the application of the law to public corruption and to robberies and extortion involving violence and threats. Because they do not often involve the economic motivation required for an exercise of the commerce power, violent crimes are often viewed by the Supreme Court as falling within the traditional domain of the police power retained by the states. Extortion under color of official right, however, involves a quid pro quo exchange of something of value for the exercise-or non-exercise - of governmental power. ${ }^{225}$ The corrupt transaction is fundamentally an economic one in which the official seeks to benefit personally from the misuse of authority. Unlike the attenuated effect on commerce from the presence of weapons near schools or from gender-motivated violence, ${ }^{226}$ corruption of public officials entails the misuse of office for personal economic gain. While bribery is an offense with roots in the common law, that background alone does not change the fundamental nature of the transaction as an essentially economic exchange among willing actors. ${ }^{227}$

common law offense of robbery; they did not address extortion under color of official right as a form of commercial activity.

${ }^{225}$ See Evans v. United States, 504 U.S. 255, 260 (1992) (holding that extortion under color of official right is essentially bribery).

${ }^{226}$ See United States v. Morrison, 529 U.S. 598 (2000); United States v. Lopez, 514 U.S. 549 (1995).

${ }^{227}$ The Court's language in Morrison indicated that if conduct was criminal, then it was not economic or commercial in nature. The Court asserted that "a fair reading of Lopez shows that the noneconomic, criminal nature of the conduct at issue was central to our decision in that case," and that "[g]ender-motivated crimes of violence are not, in any sense of the phrase, economic activity." Morrison, 529 U.S. at 613. While the crimes at issue in Lopez and Morrison involved no real economic activity, it is unlikely that the Court meant that every act that can be labeled a crime under the common law and subject to prosecution by state and local authorities is outside the authority of Congress to regulate under the Commerce Clause. Economic regulation includes the authority to prohibit conduct and punish instances in which it occurs. The Court's distinction between economic and noneconomic activities is not subject to any bright-line test, and has been criticized for its oversimplified view of activities subject to legal regulation. See Michael Richard Dimino, Recent Development, Yes, Virginia (Tech), Our Government Is One of Limited Powers: United States v. Morrison, 120 S. Ct. 1740 (2000), 24 HARV. J.L. \& PUB. POL'Y 895, 913 (2001) ("There is nothing intrinsically economic about any activity. What makes something economic or noneconomic is the context in which it is viewed. .. The Court's failure to take into account the context of the activity is likely to result in future difficulties."). 
The Hobbs Act's prohibition on extortion under color of official right is a form of commercial regulation that prohibits public officials from using their governmental authority for personal enrichment. Bribery is a criminal offense regardless of the propriety of the decision tainted by the payment, i.e., whether the exercise of authority harmed or advanced the public interest is irrelevant. While most decisions tainted by corruption are open to question, the transaction subject to congressional regulation is the quid pro quo arrangement to misuse public authority for personal gain. The Hobbs Act prohibits an economic exchange, so while it may seem odd to view a criminal statute as a form of commercial regulation, the anticorruption form of extortion meets the criteria for a proper exercise of the commerce power as set forth in Lopez and Morrison. The fact that the states have long prosecuted corruption in state and local government is not relevant to the constitutional analysis of the relationship of extortion under color of official right to the Commerce Clause.

\section{The Right of Honest Services: $§ 1346$}

The Mail Fraud statute is among the most frequently used federal provisions for prosecuting economic crimes. Shortly after the Civil War, Congress first adopted an anti-fraud statute based on the use of the mails to combat illegal interstate lotteries. ${ }^{228}$ It gradually expanded the law to reach a broad array of deceitful schemes that included any use of the mails as an aspect of the crime. ${ }^{229}$ Although the statute's roots are traceable to the common law crime of larceny by trick ${ }^{230}$ a theft offense involving a

${ }^{228}$ Act of July 27,1868 , ch. $246, \S 13,15$ Stat. 194,196 . The act provided that "it shall not be lawful to deposit in a post-office, to be sent by mail, any letters or circulars concerning lotteries, so-called gift concerts, or other similar enterprises offering prizes of any kind on any pretext whatever."

${ }^{229}$ In 1872, as part of a revision of the postal statutes, Congress expanded the lottery law to make it unlawful to "devise any scheme or artifice to defraud ... by means of the post-office establishment of the United States. . ." Act of June 8, 1872, ch. 335, 17 Stat. 283, 323 (1872). Congress adopted the Wire Fraud statute in 1952 as an extension of the Mail Fraud statute to a newer form of communication, and courts interpret the two statutes identically in determining whether the conduct constitutes a scheme to defraud. See Carpenter v. United States, 484 U.S. 19, 25 n.6 (1987) ("The mail and wire fraud statutes share the same language in relevant part, and accordingly we apply the same analysis. ...").

${ }^{230}$ See JOSHUA DRESSLER, UNDERSTANDING CRIMINAL LAW $\$ 32.10[\mathrm{~B}]$ (3d ed. 2001) ("The primary difference between larceny and false pretenses is that a thief who uses trickery to secure title, and not simply possession, of property, is guilty of false pretenses; one who merely secures possession through fraud is guilty of 
misstatement of past or present fact - the Supreme Court held early on that the provision reaches much more misconduct than the common law offense. ${ }^{231}$ The statute has continued to expand, and now covers both the use of the postal system and shipments by "private or commercial interstate carriers." 232

\section{Development of the Right of Honest Services Theory of Fraud}

Just as they used the Hobbs Act as an anti-corruption tool, federal prosecutors applied the Mail Fraud statute to instances of both public and private corruption involving dishonesty even though the statute's terms did

larceny by trick."); Stuart P. Green, Lying, Misleading, and Falsely Denying: How Moral Concepts Inform the Law of Perjury, Fraud, and False Statements, 53 HASTINGS L.J. 157, 182-86 (2001) (reviewing the development of the common law offenses based on false or misleading statements to obtain possession or title to property).

${ }^{231}$ See Durland v. United States, 161 U.S. 306, 314 (1896) ("It was with the purpose of protecting the public against all such intentional efforts to despoil, and to prevent the post office from being used to carry them into effect, that this statute was passed; and it would strip it of value to confine it to such cases as disclose an actual misrepresentation as to some existing fact, and exclude those in which is only the allurement of a specious and glittering promise."); SARAH WELLING ET AL., FEDERAL CRIMINAL LAW ANDRELATED ACTIONS $\S 17.3$, at 6(1998)("Durland was a much more radical decision, since it cut the mail fraud statute loose from its common law moorings and established that federal mail fraud was not limited to the scope of frauds punishable under state law.").

23218 U.S.C. $\$ 1341$ (2000) provides:

Whoever, having devised or intending to devise any scheme or artifice to defraud, or for obtaining money or property by means of false or fraudulent pretenses, representations, or promises, or to sell, dispose of, loan, exchange, alter, give away, distribute, supply, or furnish or procure for unlawful use any counterfeit or spurious coin, obligation, security, or other article, or anything represented to be or intimated or held out to be such counterfeit or spurious article, for the purpose of executing such scheme or artifice or attempting so to do, places in any post office or authorized depository for mail matter, any matter or thing whatever to be sent or delivered by the Postal Service, or deposits or causes to be deposited any matter or thing whatever to be sent or delivered by any private or commercial interstate carrier, or takes or receives therefrom, any such matter or thing, or knowingly causes to be delivered by mail or such carrier according to the direction thereon, or at the place at which it is directed to be delivered by the person to whom it is addressed, any such matter or thing, shall be fined under this title or imprisoned.... 
not specifically embrace corruption. ${ }^{233}$ The relationship between corruption and fraud-a type of larceny-is not immediately apparent. Federal prosecutors linked the Mail Fraud statute to corrupt activities by alleging that public officials and employees who breached a fiduciary duty by acting dishonestly for their own benefit deprived the public or an employer of the intangible right of honest services ${ }^{234}$ Courts accepted the position that a deprivation of the honest services owed by a fiduciary constituted the fraudulent taking that is normally associated with larceny and therefore sufficient to establish a scheme to defraud. Once recognized by the courts, this anti-corruption theory of mail fraud permitted a wide range of federal prosecutions of state and local officials. The Mail Fraud statute provided prosecutors with two advantages over other anti-corruption statutes. First, the mailing element was relatively easy to establish because the use of the mails need only be incident to an essential part of the scheme. ${ }^{235}$ Second, the statute did not require proof of a quid pro quo or other nefarious arrangement between an official and a third party, only that officials and employees breached a fiduciary duty by being dishonest in carrying out their responsibilities.

Although the lower federal courts readily embraced the intangible rights theory, the Supreme Court abruptly rejected it in McNally v. United States. ${ }^{236}$ The Court held that the Mail Fraud statute reached only schemes

${ }^{233}$ See Peter J. Henning, Maybe It Should Just Be Called Federal Fraud: The Changing Nature of the Mail Fraud Statute, 36 B.C. L. REV. 435, 460-61 (1995) ("Beginning in the 1970 s, federal prosecutors began using the mail fraud statute to attack political corruption at the federal, state and local level.").

${ }^{234}$ See Daniel W. Hurson, Comment, Mail Fraud, the Intangible Rights Doctrine, and the Infusion of State Law: A Bermuda Triangle of Sorts, 38 Hous. L. REV. 297, 303-04 (2001) ("The [intangible rights] doctrine is based on the belief that certain individuals are entitled to the honest and faithful services of another. . . . Failure to provide the entitled services, coupled with the use of the mails in furtherance of the failure, is a crime subject to prosecution under the mail fraud statute.").

${ }^{235}$ See Schmuck v. United States, 489 U.S. 705, 710-11 (1989); Henning, supra note 233, at 458 ("Schmuck effectively reduces the mailing element to a mere jurisdictional requirement."); Ellen S. Podgor, Mail Fraud: Opening Letters, 43 S.C. L. REV. 223, 262 (1992) ("[M]ail fraud convictions may turn on the distastefulness of the fraud, as opposed to whether the mailing actually served to further the fraudulent scheme.").

${ }^{236}$ McNally v. United States, 483 U.S. 350 (1987). The government charged a scheme to defraud the citizens of Kentucky of the right of honest services through a kickback scheme by state officials involving the award of workers compensation insurance contracts $I d$. at 352-54. Although the defendants received a significant 
to deprive victims of money or property, and not the deprivation of intangible rights "such as the right to have public officials perform their duties honestly." ${ }^{237}$ The Court's rationale for limiting the statute referred vaguely to federalism concerns - although they were not labeled as such — when it noted:

Rather than construe the statute in a manner that leaves its outer boundaries ambiguous and involves the Federal Government in setting standards of disclosure and good government for local and state officials, we read $\S 1341$ as limited in scope to the protection of property rights. If Congress desires to go further, it must speak more clearly than it has. ${ }^{238}$

McNally did not reject congressional authority to reach state and local corruption through criminal statutes. The Court hypothesized in a footnote that Congress could make the conduct of a state official a federal crime even if the state itself authorized the conduct:

It may well be that Congress could criminalize using the mails to further a state officer's efforts to profit from governmental decisions he is empowered to make or over which he has some supervisory authority, even if there is no state law proscribing his profiteering or even if state law expressly authorized it. ${ }^{239}$

The reticence to read the Mail Fraud statute broadly reflected the Court's concern with interpreting a law that had no clear connection to corruption. Therefore, McNally adopted a narrow-if somewhat crabbed-reading of the provision and then invited Congress to respond. The Court did not, however, find that Congress lacked the authority to reach state and local corruption; instead, it recognized that a clearer statement from Congress

amount of money from an insurance broker, it was unclear whether the state paid higher insurance premiums because of the scheme, and the government did not try to prove that the state suffered any loss from the defendants' conduct.

${ }^{237}$ Id . at 358 .

${ }^{238} \mathrm{Id}$. at 360 .

${ }^{239} \mathrm{Id}$. at $361 \mathrm{n} .9$. The latter part of the Court's dicta is hard to defend under federalism principles after New York $v$. United States, because it would entail a federal proscription of conduct that a state explicitly chose to permit. In that case, the federal government would be coercing a state official to refrain from acting in a way that the state determined is proper. Unlike other instances of corruption, in which there is a misuse of power for personal gain, when a state authorizes conduct there is no abuse of public authority. 
would remove any doubt about the scope of the provision, apparently including any constitutional doubt.

Congress indeed responded to the Court's invitation in McNally in short order by adopting $\S 1346$, which provides that the Mail Fraud statute "includes a scheme or artifice to deprive another of the intangible right of honest services."240 Although the legislative history of the provision is minimal, it clearly revived the anti-corruption application of the Mail Fraud statute by restoring the law to its state prior to $\mathrm{McNally}{ }^{241}$

Since $M c N a l l y$, courts have refined the right of honest services analysis by focusing on the relationship between the dishonesty of the official or employee and the benefit derived from the breach of fiduciary duty. In United States $v$. Sawyer, ${ }^{242}$ the First Circuit stated that giving improper gifts to a state legislator did not violate the Mail Fraud statute unless the government could also prove that the defendant "intended to deceive the public about that conduct." ${ }^{243}$ In United States $v$. Czubinski, ${ }^{244}$ the same court found that $\S 1346$ required that "either some articulable harm must befall the holder of the information as a result of defendant's activities, or some gainful use must be intended by the person accessing the information."245 In United States v. Bloom, ${ }^{246}$ the Seventh Circuit summarized the

24018 U.S.C. $\S 1346(2000)$.

${ }^{241}$ See 134 CONG. REC. 33,296-97 (Oct. 21, 1988) (statement of Rep. Conyers). Congress considered broader anti-corruption measures, but rejected them and instead adopted $\S 1346$, which does little more than reverse McNally's rejection of the right of honest services form of mail fraud without discussing how courts should interpret the scope of the provision. See Hurson, supra note 234, at 321 (" $[\mathrm{T}]$ he legislative history of the statute is sparse. The existing history, however, clearly states that Congress's intent enacting 18 U.S.C. $\S 1346$ was to overturn McNally and reinstate the intangible rights doctrine."); Geraldine Szott Moohr, Mail Fraud Meets Criminal Theory, 67 U. CIN. L. REV. 1, 14 n.76 (2001) (reviewing unenacted proposals to create a broad federal anti-corruption statute).

${ }^{242}$ United States v. Sawyer, 85 F.3d 713 (1st Cir. 1996).

${ }^{243}$ Id. at 733.

${ }^{244}$ United States v. Czubinski 106 F.3d 1069 (1st Cir. 1997).

${ }^{245}$ Id. at 1074 . The defendant worked for the Internal Revenue Service and made unauthorized searches of income tax returns. The government charged that the conduct violated the Wire Fraud statute because the IRS regulations prohibited unauthorized browsing of tax returns, thereby depriving the employer of the right of honest services. The First Circuit reversed the conviction because the defendant did not realize any personal gain from his violation of the internal rules of the agency: " $[\mathrm{N}]$ o rational jury could have found beyond a reasonable doubt that, when Czubinski was browsing taxpayer files, he was doing so in furtherance of a scheme to use the information he browsed for private purposes, be they nefarious or otherwise." Id. at 1075.

${ }^{246}$ United States v. Bloom, 149 F.3d 649 (7th Cir. 1998). 
requirement for a Mail Fraud violation for corruption: "Misuse of office (more broadly, misuse of position) for private gain is the line that separates run of the mill violations of state-law fiduciary duty . . . from federal crime."247

The deprivation of the right of honest services need not cause pecuniary harm to the victim, in the same sense that a theft results in the victim suffering a loss. ${ }^{248}$ Moreover, unlike a traditional larceny, under

${ }^{247}$ Id. at 655. In United States v. Brumley, 116 F.3d 728 (5th Cir. 1997) (en banc), the Fifth Circuit held that a violation of the honest services provision by a state official required proof that the "services must be owed under state law and... that they were in fact not delivered." Id. at 734. The circuit court focused on whether the breach of fiduciary duty was serious enough to violate the state's law and not just a breach of ethical guidelines for state officers, which would violate principles of federalism by involving the federal government in enforcing a code of conduct for state officials. $I d$. The Fifth Circuit's focus on state law as a means to avoid a federalism problem may sound odd, in that it requires the federal courts to ascertain the meaning of state law and find a violation of it as a condition to federal prosecution. See Hurson, supra note 234, at 319 ("Public officials whose conduct previously may at best have violated a state law (even one without significant penalties) will now have to be extra vigilant of the federal avengers, for a violation of a state law may now be all that the federal government needs to initiate an honest services mail fraud prosecution.").

If Brumley required only a violation of a state law without proof of a gain to the defendant, then the decision may be misguided. The Fifth Circuit's reason for focusing on state law, however, was that only serious misuses of authority are appropriate for federal prosecution, so that if the state imposed a duty to perform the services then the failure to adhere to that requirement would cause a significant harm. Implicit in a mail fraud prosecution is the requirement that the defendant engage in deceitful conduct for a reason, i.e., to realize a gain or deprive the victim of something of value. Brumley did not dispense with the requirement that the defendant gain a benefit through the violation of the state-imposed duty. While certainly inartful in its reliance on state law to constitute a federal offense, the Fifth Circuit imposed the requirement to ensure that mail fraud prosecutions involve the significant federal interests in punishing corruption at all levels of government and not simply instances of questionable conduct by public officials.

${ }^{248}$ In cases involving the deprivation of the right of honest services in a private setting, rather than misuse of office by a public official, courts require proof that it was reasonably foreseeable that the breach of fiduciary duty would result in an economic harm to the victim. See, e.g., United States v. Rybicki, 287 F.3d 257, 260 (2d Cir. 2002) (" $[\mathrm{I}] \mathrm{t}$ was reasonably foreseeable to the defendant that the scheme could result in some economic or pecuniary harm to the victim that is more than de minimis . . .."); United States v. Frost, 125 F.3d 346, 368 (6th Cir. 1997) ("The prosecution must prove that the employee intended to breach a fiduciary duty, and 
$\S 1346$ the gain to the miscreant need not be traceable to the harm or loss suffered by the victim. The violation results from the deception by the defendant, which breaches the defendant's fiduciary duty and triggers a personal gain to which the defendant is not otherwise entitled. ${ }^{249}$ Thus interpreted, the Mail Fraud statute is a potent anti-corruption measure because it does not require the kind of two-party exchange on which the other federal statutes in this area are premised. The misuse of authority to reward friends or divert benefits to oneself is a scheme to defraud because the defendant's breach of fiduciary duty is deceptive, and the gain is a fraud perpetrated on those who expect the person to exercise authority honestly.

\section{Constitutional Authority for Right of Honest Services Prosecutions}

Section 1346 would appear to address the federalism concern expressed in McNally regarding the scope of an ambiguous provision that reached the conduct of state and local officials. In Cleveland $v$. United States, ${ }^{250}$ the Court revisited the scope of the Mail Fraud statute and relied on McNally to reject a conviction involving misconduct at the local level. ${ }^{251}$ The defendants in Cleveland were private individuals who made false statements to obtain a state-issued gambling license, and the federal government charged a mail fraud violation for depriving the state of property. The Court held that unissued licenses held by the state were not property within the meaning of the statute, thus reaffirming the position it took in McNally that schemes to obtain property are limited to property that has an economic value in the hands of the victim. ${ }^{252}$

Cleveland did not work a significant change in the scope of the Mail Fraud statute, as McNally did through its narrow interpretation that temporarily eliminated the right of honest services theory of prosecution. In supporting its conclusion that an unissued license was not property, the

that the employee foresaw or reasonably should have foreseen that his employer might suffer an economic harm as a result of the breach.").

${ }^{249}$ See Moohr, supra note 241, at 48 ("In these frauds, the defendant uses his or her position to realize a goal of obtaining some benefit. Using the actor's ultimate objective - to accept a bribe, to convert property to his or her own use, or exploit a conflict of interest-focuses the inquiry on the defendant's purpose, whether that objective causes a loss to the victim of the deceit or a gain of a benefit from a third party.").

${ }^{250}$ Cleveland v. United States, 531 U.S. 12 (2000).

${ }^{251}$ Id. at 26-27.

${ }^{252}$ See id. at 22 ("If Cleveland defrauded the State of 'property,' the nature of that property cannot be economic."). 
Court noted that permitting such a prosecution "would subject to federal prosecution a wide range of conduct traditionally regulated by state and local authorities," not read the mail fraud statute to place under federal superintendence a vast array of conduct traditionally policed by the States." ${ }^{254}$ Unlike the concern expressed in McNally about federal interference in the operation of state and local governments, Cleveland adopted the rationale of Lopez and Morrison that federal prosecution of crimes "traditionally regulated by state and local authorities"255 is problematic. The Court did not cite any of its federalism decisions to explain its position, although the language clearly implied at least a concern with the scope of the Mail Fraud statute based on federalism limitations.

Although McNally and Cleveland refer obliquely to federalism concerns, the Court has never had to address directly the question of whether federalism imposes any substantive limit on the Mail Fraud statute. Unlike the Hobbs Act, which is based on the Commerce Clause, the Mail Fraud statute is based in part on the Postal Clause, which authorizes Congress to "establish Post Offices and Post roads." exclusive authority over the postal system, and the Court early on upheld the validity of the Mail Fraud statute as a proper excise of that power when coupled with the Necessary and Proper Clause. ${ }^{257}$ The statute links the common law offense of larceny by trick with congressional authority over the mails to create a federal crime. The criminal prohibition originated in an era when local scam artists took advantage of an expanding economy to extend their reach through the mails to carry out frauds on a larger scale,

${ }^{253}$ Id. at 24.

${ }^{254}$ Id. at 27.

${ }^{255}$ Id. at 14.

${ }^{256}$ U.S. CONST. art. I, $\S 8$, cl. 7. Professor Kurland criticized the use of the Postal Clause, rather than the Guarantee Clause, as the basis for enacting $\S 1346$, because the right of honest services provision "merely reinstates and perpetuates many of the irrational loopholes and inconsistencies inherent in tying the use of the intangible rights theory to cases where a sufficient use of the mails or wires can be established." Kurland, Guarantee Clause, supra note 66, at 490.

${ }^{257}$ See Ex parte Jackson, 96 U.S. 727, 732 (1878) ("The right to designate what shall be carried necessarily involves the right to determine what shall be excluded."); see also Badders v. United States, 240 U.S. 391, 393 (1916) (Congress has the authority to prohibit the use of the mails to carry out a fraudulent scheme "whether it can forbid the scheme or not."). 
and the federal statute was a response to a type of criminal activity that traditionally came within the authority of the states to prosecute. ${ }^{258}$

The postal power is an exclusive grant of authority to Congress to establish and control the federal postal system, ${ }^{259}$ and the Court has not hesitated to uphold congressional power under the clause to punish misuse of that system. In Ex parte Rapier, ${ }^{260}$ decided in 1892, the Court rejected an argument that the Mail Fraud statute was unconstitutional because

${ }^{258}$ Congress expanded the Mail Fraud statute in 1994 to include.the use of "any private or commercial interstate carrier" in executing the fraudulent scheme. 18 U.S.C. $\S 1341$ (2003), amended by Violent Crime Control and Law Enforcement Act of 1994, Pub. L. No. 103-332, $§ 250006,108$ Stat. 1796, 2087. This part of the statute is based on the commerce power, rather than the postal power. In Lopez, the Court explained that

we have identified three broad categories of activity that Congress may regulate under its commerce power. First, Congress may regulate the use of the channels of interstate commerce. Second, Congress is empowered to regulate and protect the instrumentalities of interstate commerce, or persons or things in interstate commerce, even though the threat may come only from intrastate activities. Finally, Congress' commerce authority includes the power to regulate those activities having a substantial relation to interstate commerce....

United States v. Lopez, 514 U.S. 549, 558-59 (1995) (internal citations omitted). Under the tripartite division of congressional commerce power described in Lopez, the provision comes within the second category (protection of an instrumentality of interstate commerce) and not the third category (activities that affect interstate commerce). See Henning, supra note 233, at 472 (The interstate or commercial carrier element of the Mail Fraud statute "is similar to the second category of statutes [under Lopez], requiring proof that an instrumentality of interstate commerce is used for the purpose of executing the fraudulent scheme."). The statutes at issue in Lopez and Morrison purported to be an exercise of congressional authority to regulate non-commercial conduct that indirectly affected interstate commerce. This required the Court to give close scrutiny to whether the conduct had the requisite effect under the Commerce Clause. In Morrison, the Court noted that the gender-motivated violence was not an economic activity, and therefore pushed federal authority into an area-violent crime - traditionally regulated by the states. See United States v. Morrison, 529 U.S. 598 (2000). Even if the private or commercial carrier basis for a mail fraud prosecution falls in the third Lopez category, the crime involves economic activity - the gain to the defendant from the scheme and the loss by a victim. Unlike the statutes the Court invalidated in Lopez and Morrison, the Mail Fraud statute stands on a substantially stronger footing under the Commerce Clause.

\footnotetext{
${ }^{259}$ See supra note 256.

${ }^{260}$ Ex parte Rapier, 143 U.S. 110 (1892).
} 
Congress could not regulate acts that had traditionally been subject to state criminal laws. The Court held, "It is not necessary that congress should have the power to deal with crime or immorality within the states in order to maintain that it possesses the power to forbid the use of the mails in aid of the perpetration of crime or immorality."261 The Mail Fraud statute necessarily incorporates a substantial overlap with state law offenses because Congress enacted the statute to reach a common law offense that was being executed in a new way involving the use of a federal facility. ${ }^{262}$

The Court's reference in Cleveland to the divide between state and federal authority misconstrued the scope of congressional authority under the postal power. While the Commerce Clause analysis in Lopez and Morrison invalidated statutes at the outer limit of the Commerce Clause, the Mail Fraud statute is based, in part, on a different source of constitutional authority. To the extent that the statute is an exercise of congressional authority over the mails, it is not clear why federalism limitations on the commerce power to reach local crimes would be relevant. In the early challenges to the Mail Fraud statute, the Court readily accepted the fact that the law reaches crimes already subject to state prosecution because the federal interest arises from the use of a facility of the national government over which Congress has exclusive control. Moreover, even that part of the statute based on the Commerce Clause involves a stronger basis for congressional regulation-protection of the channels of interstate commerce-than a statute based only on the indirect effects of conduct on interstate commerce.

Federalism limits the scope of Congress' authority to regulate commerce, but it does not impose an impenetrable barrier between what may be considered truly national and truly local with regard to every regulation under that grant of power. The federal and state governments do not operate in a disjunctive fashion, and there has always been a substantial

${ }^{261}$ Id. at 134; see also Jackson, 96 U.S. at 732 (The Court held that the power granted to Congress under the Postal Clause "embraces the regulation of the entire postal system of the country. The right to designate what shall be carried necessarily involves the right to determine what shall be excluded.").

${ }^{262}$ See Rapier, 143 U.S. at 134 ("When the power to establish postoffices and post-roads was surrendered to the congress, it was as a complete power; and the grant carried with it the right to exercise all the powers which made that power effective. It is not necessary that congress should have the power to deal with crime or immorality within the states in order to maintain that it possesses the power to forbid the use of the mails in aid of the perpetrations of crime or immorality."). 
overlap in the criminal authority of each level of government. ${ }^{263}$ As the origins of the Mail Fraud statute demonstrate, conduct subject to local prosecution can also implicate strong federal interests, which permit Congress to exercise its power to enact criminal legislation to reach the same acts.

The federal interest includes the prosecution of public corruption, and $\S 1346$ is a clear congressional mandate that federal authority can be used to police misconduct by state and local officials. ${ }^{264}$ The scope of the provision is broad, but it does not interfere with or denigrate the power of the states by allowing for federal prosecution of conduct that is not otherwise improper. ${ }^{265}$ While the Court in McNally expressed concern that

${ }^{263}$ See Pẻter J. Henning, Misguided Federalism, 68 Mo. L. REV. 389, 412 (2003) ("The assertion in Morrison-and to a lesser extent in Lopez-that federalism required that the states have exclusive authority over some types of criminal conduct is flawed because the Court's premise is unsupportable."); Susan R. Klein, Independent-Norm Federalism in Criminal Law, 90 CALIF. L. REV. 1541, 1553 (2002) (" [W]here federal criminal laws regulate conduct already regulated by the states, such federal legislation does not displace the state criminal-justice system, but rather supplements it with concurrent jurisdiction."). But see George D. Brown, Should Federalism Shield Corruption?-Mail Fraud, State Law and Post-Lopez Analysis, 82 CORNELL L. REV. 225, 252-53 (1997) [hereinafter Brown, Corruption] ("[A]ssertions of authority under any grant of power should now be open to question in order to preserve the principle of a limited national government which Chief Justice Rehnquist identified [in Lopez] as fundamental. If it is a stretch to go from 'commerce' to regulating guns near schools, it may also be a stretch to go from 'establishing Post Offices and Post Roads' to criminalizing misconduct by state and local officials."). Professor Brown argues that federalism provides an "external limit" on Congress that can be enforced by the courts to limit the scope of its power to enact legislation, and that the interpretation of $\S 1346$ be based on whether the conduct violated state law; this test would avoid federal interference. $I d$. at 261 . It is not clear whether the argument is that $\S 1346$ is unconstitutional if there is no reference to state law, or whether particular prosecutions might be impermissible under principles of federalism. That distinction is important because federalism limits the power to Congress to regulate, but if the statute is a proper exercise of constitutional authority, then particular prosecutions would be constitutional so long as the elements of the crime can be established.

${ }^{264}$ See Rapier, 143 U.S. at 134 ("[I]t must be left to congress, in the exercise of a sound discretion, to determine in what manner it will exercise the power it undoubtedly possesses.").

${ }^{265}$ Professor Brown asserts that the right of honest services provision might interfere with the role of the states as "laboratories" for experimentation, a valuable role for the states that is protected by federalism. Brown, Corruption, supra note 263 , at 275 . The argument is that federal prosecutions usurp the power of the states 
the right of honest services theory of fraud might somehow inject the federal government into setting ethical standards for the states, ${ }^{266}$ the application of $\S 1346$ shows that the statute requires proof of the misuse of authority for personal gain and not simply the breach of a vague notion of fairness or moral virtue. ${ }^{267}$ The Constitution's Anti-Corruption Legacy

by enabling the federal government to criminalize the exercise of legitimate state power in a mail fraud case. The problem with the argument as applied to the Mail Fraud statute is that the federal law does not preclude or inhibit the states from adopting their own approaches to the exercise of their authority unless the individual official is using the authority for personal gain. While references to the states as laboratories of innovation has strong rhetorical appeal, it is unlikely that a federal prosecution will ever involve conduct by a local official that is explicitly authorized by a state government because there would be no deprivation of the honest services owed to the state and citizenry. More importantly, $\S 1346$ reaches the misuse of authority, so there is no federal interference with the state's exercise of its authority or autonomy, except to the extent that a dishonest official who is convicted of mail fraud under $\S 1346$ may not be available for future work, a trivial loss.

${ }^{266}$ McNally v. United States, 483 U.S. 350, 360 (1987) (refusing to interpret the statute in a way that "involves the Federal Government in setting standards of disclosure and good government for local and state officials").

${ }^{267}$ But see Sara Sun Beale, Comparing the Scope of the Federal Government's Authority to Prosecute Federal Corruption and State and Local Corruption: Some Surprising Conclusions and a Proposal, 51 HASTINGS L.J. 699, 715 (2000) (Federal prosecutors have used $\S 1346$ "to reach conduct on the part of state and local officials that would be subject, at most, to discipline or removal from office under federal ethical rules."). Professor Beale argues that, in order to avoid expanding federal jurisdiction, $\S 1346$ should be limited to cases which could be charged as a violation of $\S 201$ if the official were a federal officer to avoid expanding federal jurisdiction. It is not clear how the statute could be rewritten by judicial interpretation of its terms when the provision reaches all types of fraud-including the right of honest services under $\S 1346$-and not just two-party exchanges involving bribery and gratuities. As interpreted by the courts, $\S 1346$ requires dishonesty in the exercise of authority resulting in an undeserved gain; therefore, kickback schemes or other types of conduct to reap an improper reward are subject to the criminal prohibition. Professor Beale also asserts that the Mail Fraud statute is not applied to federal officials to the same extent that it is to state and local officials, but that position may be mistaken. Id. at 717 ("To this point, the honest services theory has seldom been applied in cases involving federal officials."). There have been high-profile mail fraud prosecutions of members of Congress, see United States v. Rostenkowski, 59 F.3d 1291 (D.C. Cir. 1995) (mail fraud charges against former Representative Dan Rostenkowki, who chaired the House Ways and Means Committee); In re Ford, 987 F.2d 334 (6th Cir. 1992) (mail fraud charges against Representative Harold Ford); United States v. Biaggi, 
supports the exercise of congressional authority in $\S 1346$ to permit federal prosecution of a wide range of misconduct in all levels of government.

\section{CONCLUSION}

The Constitution contains provisions designed to prevent corruption in the administration of the national government and, indirectly, structural protections to limit the effects of corruption in the state governments. The division of authority between the federal government and the states operates on the assumption that each government will act properly, although perhaps in its own self-interest, by advancing its own policies. Out of the balance between federal and state power comes the protection of the people.

That balance is skewed when corruption the misuse of authority for personal gain-taints the operation of any government. Federalism creates a healthy competition, but it does not permit one level of government to operate in a corrupt manner. The notion of federal prosecution of the

909 F.2d 662 (2d Cir. 1990) (mail fraud charges against former Representative Mario Biaggi); United States v. Diggs, 613 F.2d 988 (D.C. Cir. 1979) (mail fraud charges against Representative Charles Diggs); and congressional aides, see United States v. Dixon, 658 F.2d 181 (3d Cir. 1981). For mail fraud prosecutions against officers of the executive branch, see United States v. Hubbell, 44 F. Supp. 2d 1 (D.D.C. 1999), rev'd in part, 177 F.3d 111 (D.C. Cir. 1999) (mail fraud charges against former Associate Attorney General Webster Hubbell); United States v. Espy, 23 F. Supp. 2d 1 (D.D.C. 1998) (mail fraud charges against former Secretary of Agriculture Mike Espy); see also United States v. Sun-Diamond Growers of Cal., 964 F. Supp. 486 (D.D.C. 1997) (mail fraud charges involving scheme to deprive employer of lobbyist of its right to honest services related to gratuities paid to former Secretary of Agriculture Mike Espy).

While there are more prosecutions of state and local officials involving $\S 1346$ than prosecutions of federal officials, that may reflect the large disparity in the number of officials at different levels of government and the fact that greater economic interests that might attract corrupting parties are at stake in decisions by local governments, such as zoning, condemnation, service contracts, etc. There does not appear to be any evidence that the government is creating a different threshold for violating $\S 1346$ based on the level of government at which the corruption occurred. Moreover, the view that the federal government is somehow policing only ethical violations that are at best questionably criminal has little support in the cases. For example, in United States v. Sawyer, 85 F.3d 713, 728 (1st Cir. 1996), the charges against the lobbyist for his gifts to a state legislator were much more than mere ethical lapses but involved significant corruption of the political process. 
corrupt use of power by any official, federal or state, protects the benefits afforded by the division of power under federalism. The constitutional design does not create wholly separate spheres of authority, at least not in a way that would shield from federal prosecution state officers' abuse of authority for personal gain. The Anti-Corruption Legacy of the Constitution makes it clear that the federal statutes used to prosecute corruption at all levels of government comply with federalism by ensuring that the balance between the states and the national government remains a healthy competition, not one tainted by the improper exercise of official authority. 